This item was submitted to Loughborough's Research Repository by the author.

Items in Figshare are protected by copyright, with all rights reserved, unless otherwise indicated.

\title{
A BIM-aided construction waste minimisation framework
}

\section{PLEASE CITE THE PUBLISHED VERSION}

http://dx.doi.org/10.1016/j.autcon.2015.07.020

\section{PUBLISHER}

(c) Elsevier

\section{VERSION}

AM (Accepted Manuscript)

\section{PUBLISHER STATEMENT}

This work is made available according to the conditions of the Creative Commons Attribution-NonCommercialNoDerivatives 4.0 International (CC BY-NC-ND 4.0) licence. Full details of this licence are available at: https://creativecommons.org/licenses/by-nc-nd/4.0/

\section{LICENCE}

CC BY-NC-ND 4.0

\section{REPOSITORY RECORD}

Liu, Zhen, Mohamed Osmani, Peter Demian, and Andrew N. Baldwin. 2015. "A Bim-aided Construction Waste Minimisation Framework”. Loughborough University. https://hdl.handle.net/2134/18885. 


\title{
A BIM-aided construction waste minimisation framework
}

\author{
Zhen Liu* (z.liu2@lboro.ac.uk) \\ Mohamed Osmani (m.osmani@lboro.ac.uk) \\ Peter Demian (P.Demian@lboro.ac.uk) \\ Andrew Baldwin (a.n.baldwin@lboro.ac.uk) \\ School of Civil and Building Engineering, Loughborough University, Loughborough, \\ Leicestershire LE11 3TU, United Kingdom \\ *Corresponding author.
}




\section{Abstract:}

At present, there are insufficient design decision making tools to support effective construction waste minimisation evaluation and implementation throughout all design stages. A limited but growing body of recent literature suggests that Building Information Modelling has the potential to assist architects to minimise design waste on their projects. The research reported in this paper is the first attempt to develop a design decision making framework for improving construction waste minimisation performance through Building Information Modelling. The potential use of Building Information Modelling to drive out construction waste in building design was investigated through a questionnaire survey and follow-up interview with the top 100 architectural practices in the United Kingdom. An industry reviewed 'Building Information Modelling-Aided Construction Waste Minimisation Framework' was developed based on the results of the literature review, questionnaire data and interview data. The Framework is intended to act as an integrated platform for designing out waste decision making, by providing informed Building Information Modelling-driven guidance to address waste causes throughout design stages.

\section{Keywords:}

Construction waste minimisation; Building Information Modelling; Building design; Architects

\section{Introduction}

Construction and demolition activities generate 32\% [19] and 44\% [22] of all waste generated within United Kingdom (UK) and England respectively. As such, the construction industry has been targeted by the UK government as a priority sector for the reduction of carbon emissions, energy consumption, and material resources usage. The latter increased from 420 million tonnes in 2003 [26] to 470 million tonnes in 2013 [22]. Currently, the UK construction industry produces 120 million tonnes of waste [79], of which 13 million tonnes are materials that have been delivered to the site but are never used [20]. Owing to a continuous increase of construction waste, the Strategy for Sustainable Construction [33] set a target of halving construction, demolition, and excavation waste to landfill by 2012 compared to 2008. Defra [22] confirmed that the target has been achieved except for increased excavation waste and called for further waste prevention actions, including designing out waste. Moreover, reducing construction waste has been driven by economic and environmental considerations due to the cost of waste, which relates to landfill tax that increased from $£ 32 /$ tonne in 2008 to $£ 80 /$ tonne in 2014 [37], and it is considered around 15 times that of disposal [56].

At present, the construction industry is responsible for about $32 \%$ of landfill waste and $25 \%$ of all used raw materials in the UK [66]. Thus, the construction industry has been exploring and developing approaches to minimise waste generation throughout the project lifecycle stages by employing sustainable building design and reducing waste during the design process [41]. The Green Overlay to the Royal Institute of British Architects (RIBA) Outline Plan of Work, that organise the process of building design projects into a number of key stages, has been introduced to provide a process for helping architects and project stakeholders to embed sustainable design strategies (e.g. energy and water efficiency, and carbon and waste reduction) in their design projects [69]. However, construction waste minimisation (CWM) has been paid little attention in the Green Overlay. At present, there are insufficient design decision making tools to support effective CWM evaluation and implementation throughout building design stages [59]. Recently, the UK Government Construction Strategy mandated the use of fully collaborative Building Information Modelling (BIM) on public sector projects by 2016 [34]. Furthermore, the UK Construction 2025 Strategy recognised that BIM has the potential to reduce construction waste during design and construction stages [36]. The RIBA recently issued a BIM Overlay to the RIBA Outline Plan of Work in conjunction with the Green Overlay [70], which provides stage-by-stage guidance to assist architects to design and manage construction projects through the use of BIM. However, no efforts have been made to date to develop BIM-aided CWM design decision making tools and methodologies, which is the aim of this paper. Within the context of this research, construction waste is defined as a material or product which needs "to be transported elsewhere from the construction site or used on the site itself other than the intended specific purpose of the project due to damage, excess or non-use, or 
Z. Liu, M. Osmani, P. Demian \& A. Baldwin (2015) A BIM-aided construction waste minimisation framework. Automation in Construction, Volume 59, November 2015, Pages 1-23.

which cannot be used due to non-compliance with the specifications, or which is a by-product of the construction process" [78].

\section{Construction waste minimisation}

Construction Waste Minimisation is a process, which helps to prevent, eliminate, or reduce waste at its source during design [16, 59, 71]. Prevention includes all activities that can reduce the amount of construction waste, which involves minimising waste generation at source and reducing waste before it enters the waste stream [4, 21, 60]. A significant proportion of construction waste occurs during the early design stages [7, 24, 27, 72]. Around 33\% of waste may be directly influenced by design decisions [39]. WRAP [82] indicated that there is a greater opportunity for reducing waste at the design stage than later stages, because fundamental design decisions related to building material, sharpness of form, size and complexity, are more likely to have a significant impact on waste.

There is agreement in the literature that construction waste during design is mainly related to design changes [3, 7, 24, 27], ineffective coordination and communication [28, 43, 58, 59], material specification [24, 58, 60, 62], design and detailing complexity [43, 58,60,63], and design and construction detail errors [27, 28,60,61]. A number of studies indicated that design changes during the construction stage, known as re-work, are major waste generation causes. It has been reported that causes of re-work are mainly due to client changes during site operations and poor communication among project stakeholders [49]. Al-Hajj and Hamani [2] argued that poor design-related material off-cut waste is clearly outside the control of the contractors but is within the control of the designers. A study conducted by Sinclair [77] suggested that designers have a great deal of influence over construction waste generation during various project stages. However, there is a lack of understanding by designers on causes of design waste [59]. Effective coordination and communication is critical to minimising construction waste at the design stage [83]. Additionally, limited 'know-how' and incoherent coordination and communication between project members affect design waste [59]. Some studies suggested that coordination and communication of design decision making are partly influenced by the late involvement of the contractor to provide consultation on waste reduction during design stages [7, 59, 60]. Rounce [72], and Al-Hajj and Hamani [2] equally believed that construction waste causes should be taken into consideration through better management of the design process.

The majority of current CWM practices focus on the construction stage, such as on-site waste auditing [9] and construction supply chain management [17], with less effort being paid to reduce waste during design. Construction waste forecasting tools, such as design-based waste assessment [25] and online waste forecasting [84] have been used to assist construction waste reduction during design stages. These tools aimed to capture live data of waste and provide improvements to resource efficiency in terms of waste minimisation; however, they do not consider CWM decision making during design stages.

Emerging information management-related technologies, such as bar coding systems [13], Global Positioning System (GPS) [47], E-commerce system simulation [14], and Geographic Information Systems (GIS) [6] are being adopted for construction waste research. Most recently, Liu et al. [48] suggested that BIM techniques can be used by architects as a platform for minimising construction waste in their design projects.

\section{Building information modelling (BIM)}

There is still no single, widely accepted definition of BIM. BIM is currently being gradually used to achieve various design, construction, and facility management performance targets [40, 46, 67, 76]. These include improving and enhancing simulation and analysis, coordination and communication for collaborative working, lifecycle information assessment and management, and sustainable design across project lifecycle stages, as shown in Fig. 1, which indicates that the current use of BIM appears to bring about benefits throughout a project lifecycle. 


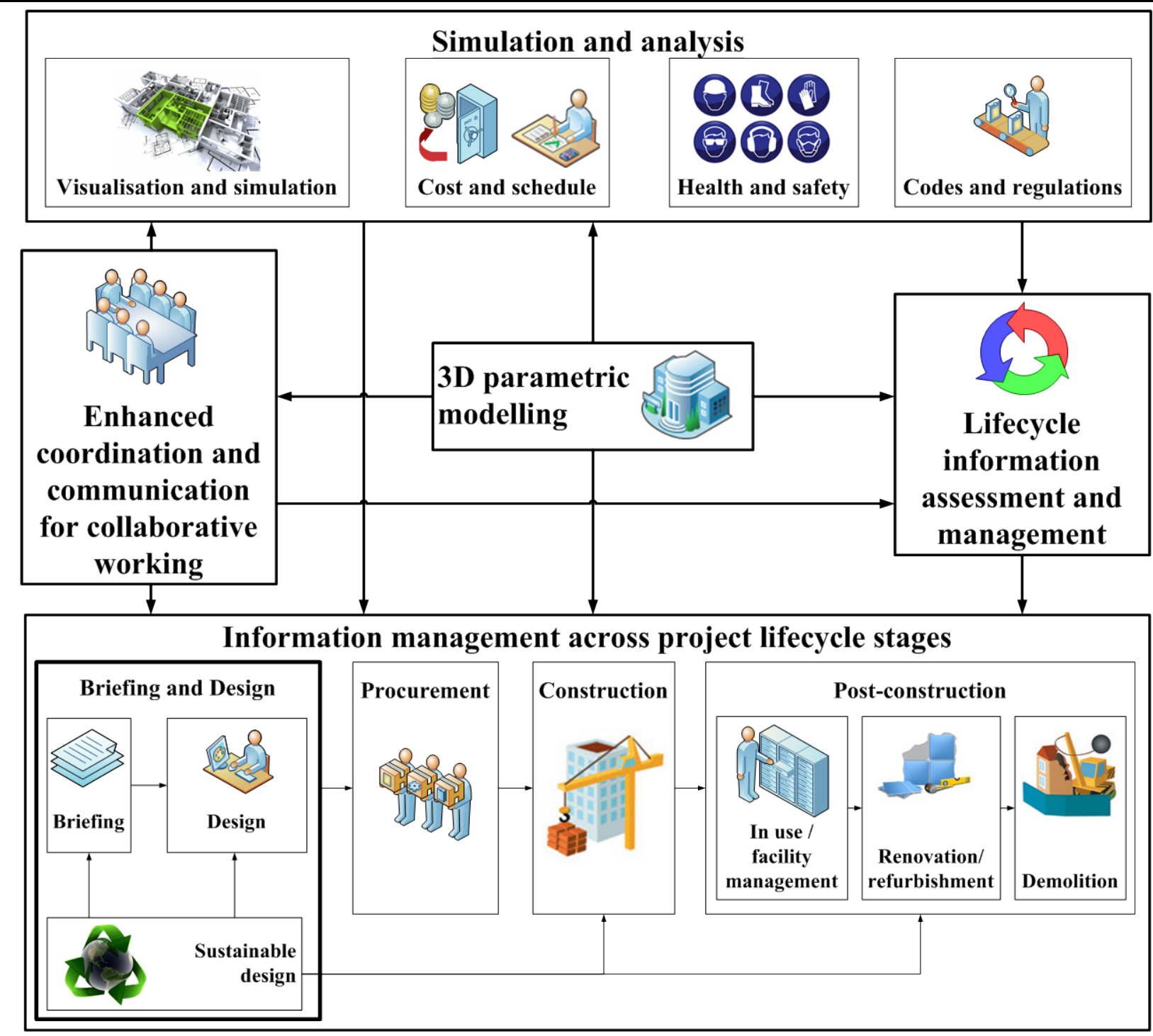

Fig. 1. Conceptual framework of current use of BIM (devised by the authors based on the literature)

BIM is thought to provide significant enhancements in detailing [30], visualisation and simulation [23], clash detection [30], and improved project performance in terms of coordination and communication [45]. When generating layouts or designing details, BIM allows its users to annotate building components with data/parameters which can be used for analysis to meet sustainable design requirements [87]. Architects and engineers have used visualisation and simulation within BIM to improve their knowledge of design and increase their spatial cognition [42]. It is important for project team members to evaluate the design via visualisation and simulation in BIM during early design stages [88]. The enhanced coordination and communication for collaborative working processes within BIM can determine the success of the project BIM is implemented to manage conflicts between project participants' models, known as clash detection [44].

BIM-enhanced coordination and communication for collaborative working are fundamental features offered by BIM [23]. They influence all aspects of construction projects across all lifecycle stages and have a significant impact on design and construction, where BIM helps to streamline processes that use 3D parametric models and facilitates communication among disparate project stakeholders such as client, design team and contractor, to achieve a better understanding and quicker decision making [29, 75]. This decision making requires effective coordination and communication to be delivered without any interoperability problems at company level, design team level, and project level. Enhanced coordination and communication for collaborative working via BIM is achieved through enhanced human communication, innovative 
visualisation, a rich knowledge database, and parametric 3D interaction. The current use of BIM for coordination is not only to ensure design-phase coordinated 3D models, but also in monitoring the scale and speed of construction and in assigning responsibility for site management and work coordination [18]. This results in a 3D parametric BIM model as a common method to ensure enhanced coordination and communication for collaborative working by the various project team members on most relevant briefing, design and construction issues. Associating 3D parametric BIM models with on-line tools, such as a BIM model server and web-based forums, would improve interoperability performance [68].

BIM standards represent rules allowing users to develop and apply BIM efficiently and consistently [51], especially when communication encompasses different project teams, specialists, and suppliers during a project [38]. There are several BIM standards, including BS 1192:2007, which was recently developed as a Publicly Available Specification (PAS 1192-2:2013), and a Diagram of BIM Maturity Levels, which has been widely adopted by the UK's construction industry in recent years [35, 55]. BS 1192:2007 was published by the British Standards Institution to provide guidelines to support collaboration by defining the rules for modelling, publishing, and sharing information [10]. These apply to all parties who are involved in the preparation and use of information throughout the construction project lifecycle. PAS 1192-2:2013 was developed in line with BS 1192:2007 to specify requirements in achieving BIM Level 2 by focusing on project delivery [11].The Diagram of BIM Maturity Levels, known as Bew and Richards's maturity diagram (Fig. 12), attempts to summarise the BIM evolutionary process originally presented by Mark Bew and Mervyn Richards in 2008 and updated in 2012 in line with the UK Construction Strategy 2012. The maturity levels (Levels 0, 1, 2, and 3) are widely referred to in the construction industry, as BIM implementation is phased in by the Government Construction Strategy 2011. This required large public projects to implement Level 2 BIM from summer 2012 and all public projects have to fully collaborate with BIM-associated asset information, documentation, and data being electronic by 2016. The latest UK Government Construction Strategy, Construction 2025 [36] calls for all central government departments' projects, irrespective of project size, to implement at least Level 2 BIM from 2016, and expects that both the UK government and construction industry will move to a new era of implementing Level 3 BIM from 2016 to 2025 to save cost, reduce carbon emission, build more sustainable buildings, and establish Digital Built Britain.

Further development and implementation of BIM have the potential to improve sustainable building design and construction performance, such as integrated computational fluid dynamics analysis, energy analysis, acoustic simulation and water analysis, etc. [8].

\section{BIM potential for construction waste minimisation}

WRAP [85] and O'Reilly [57] argued that CWM could be supported and enhanced through the use of BIM, particularly during the design stages. An increasing body of literature suggested the importance of investigating the impact of adopting information communication-related techniques and tools, such as BIM, to assist in minimising construction waste during building design and construction $[73,80]$. Few studies have attempted to investigate the use of BIM to address construction waste generation. These include BIM-enhanced coordination [1]; structural reinforcement of rebar waste reduction [65]; material resource efficiency [85]; demolition waste management [15, 31]; and on-site waste management improvement [32].

Additionally, WRAP [86] developed guidelines in improving and achieving resource efficiency through the implementation of BIM, attempting to align BIM with lifecycle stages of building projects, from concept to handover. However, these guidelines focused on energy efficiency and carbon reduction, and gave little consideration to CWM.

There is a lack of decision making tools for CWM during design in the literature [59]. Moreover, the literature revealed that there are no BIM-related tools to support waste minimisation throughout building design stages. This emphasises the need for a comprehensive investigation to explore the potential of BIM to reduce construction waste in building design, which is the focus of this paper.

\section{Research method}

A mixed research methods approach was adopted in this research to establish a coordinated correlation between BIM and 
CWM decision making during design, with the consequences for action articulated in a resulting BIM-aided CWM framework. The research methodology included two data collection instruments: a questionnaire survey and a face-to-face semi-structured follow-up interview. The questionnaire survey assisted in exploring the potential of BIM for CWM during design, which was divided into six sections comprising a total of 14 questions. The UK top 100 architectural practices, as listed in 2010 Building Magazine [12], were selected as the sample for this research to capture their views on the potential use of BIM to reduce construction waste during design stages. The questionnaire survey achieved a $50 \%$ response rate. The findings of the questionnaire were used to further investigate the relationship between BIM and CWM through face-to-face semi-structured interviews that engaged 11 questionnaire respondents. The sampling approach of the interview was based on the selection of participating architects who indicated that they routinely use BIM to enhance sustainable building design in their projects, and so was determined by the questionnaire results.

A BIM-aided construction waste minimisation (BaW) framework was designed and developed based on findings from literature review, questionnaire, and interview. The BaW Framework was intended to act as a BIM-aided CWM decision making process across all design stages. The BaW Framework was industry reviewed through a validation questionnaire and face-to-face semi-structured interview, involving six participating architects from previous data collection stages. They were purposely selected for the BaW Framework review process owing to their experience of sustainable building design practices through the use of BIM in building design projects.

Subsequently, statistical descriptive analysis and means comparison analysis using SPSS V19 were adopted for the quantitative questionnaire data; and content analysis was adopted for the qualitative interview data. The questionnaire respondents were divided into two groups according to their experiences: Group A (28 responding architects) had used BIM for sustainable building design, whilst Group B (22 responding architects) had not.

\section{Results}

The results of the questionnaire survey and interview related to current BIM design practices and their potential for reducing construction waste generation, BIM potential to address construction waste causes, and BIM potential for CWM throughout building design stages are presented in the sections below.

\subsection{Current BIM design practices and their potential for reducing construction waste generation}

The questionnaire respondents were asked to rate the extent to which BIM was used for specific activities during design stages, using a scale of 1-4 (1=never used, 2=used in few projects, 3=used in most projects, 4= used in all projects). The results in Table 1 show that responding architects used BIM for visualisation and simulation; improving project performance in terms of coordination and communication, clash detection, and detailing in most of their projects. Further, there is no statistically significant difference between the mean scores of Group A and Group B responses on the use of BIM for assisting design activities in their projects, such as visualisation and simulation, improved coordination and communication, detailing, checking compliance with codes and regulations, and sourcing/supply chain. The Two-Tailed Significance (Sig. (2-Tailed)) values of the Independent Samples T-test for Equality of Means between the two groups are greater than 0.05 , as shown in Table 1 . The difference is likely due to chance or sampling error. 
Table. 1. The current use of BIM for activities during design (questionnaire's responses)

\begin{tabular}{|c|c|c|c|c|c|c|c|c|c|c|c|c|c|c|c|}
\hline \multirow{4}{*}{$\begin{array}{c}\text { Groups of the } \\
\text { Use of BIM } \\
\text { for } \\
\text { Sustainable } \\
\text { Building } \\
\text { Design (SBD) } \\
\text { Strategies }\end{array}$} & \multicolumn{4}{|c|}{ Group Statistics } & \multirow{4}{*}{ Activities During Design } & \multicolumn{10}{|c|}{ Independent Samples Test } \\
\hline & \multirow[t]{3}{*}{$\mathbf{N}$} & \multirow[t]{3}{*}{ Mean } & \multirow[t]{3}{*}{$\begin{array}{c}\text { Std. } \\
\text { Deviation }\end{array}$} & \multirow[t]{3}{*}{$\begin{array}{l}\text { Std. } \\
\text { Error } \\
\text { Mean }\end{array}$} & & \multirow[t]{3}{*}{ Equal Variances Assumption } & \multicolumn{2}{|c|}{$\begin{array}{l}\text { Levene's } \\
\text { Test for } \\
\text { Equality of } \\
\text { Variances } \\
\end{array}$} & \multicolumn{7}{|c|}{$\mathrm{t}$-test for Equality of Means } \\
\hline & & & & & & & \multirow[t]{2}{*}{$\mathrm{F}$} & \multirow[t]{2}{*}{ Sig. } & \multirow[t]{2}{*}{$\mathbf{t}$} & \multirow[t]{2}{*}{ df } & \multirow[t]{2}{*}{$\begin{array}{c}\text { Sig. } \\
\text { (2-tailed) }\end{array}$} & \multirow[t]{2}{*}{$\begin{array}{c}\text { Mean } \\
\text { Difference }\end{array}$} & \multirow[t]{2}{*}{$\begin{array}{l}\text { Std. Error } \\
\text { Difference }\end{array}$} & \multicolumn{2}{|c|}{$\begin{array}{c}95 \% \text { Confidence Interval of } \\
\text { the Difference }\end{array}$} \\
\hline & & & & & & & & & & & & & & Lower & Upper \\
\hline Yes (Group A) & 28 & 2.57 & .997 & .188 & Visualisation and simulation & Equal variances assumed & .044 & .834 & 1.777 & 48 & .082 & .526 & .296 & -.069 & 1.121 \\
\hline No (Group B) & 22 & 2.05 & 1.090 & .232 & & Equal variances not assumed & & & 1.758 & 43.180 & .086 & .526 & .299 & -.077 & 1.129 \\
\hline Yes (Group A) & 28 & 2.39 & .916 & .173 & Improved coordination and communication & Equal variances assumed & .045 & .833 & 1.764 & 48 & .084 & .484 & .274 & -.068 & 1.035 \\
\hline No (Group B) & 22 & 1.91 & 1.019 & .217 & & Equal variances not assumed & & & 1.741 & 42.739 & .089 & .484 & .278 & -.077 & 1.044 \\
\hline Yes (Group A) & 28 & 2.25 & .928 & .175 & Clash detection & Equal variances assumed & .131 & .719 & 2.581 & 48 & .013 & .659 & .255 & .146 & 1.173 \\
\hline No (Group B) & 22 & 1.59 & .854 & .182 & & Equal variances not assumed & & & 2.607 & 46.745 & .012 & .659 & .253 & .150 & 1.168 \\
\hline Yes (Group A) & 28 & 2.18 & .945 & .179 & Detailing & Equal variances assumed & .061 & .806 & 1.121 & 48 & .268 & .315 & .281 & -.250 & .880 \\
\hline No (Group B) & 22 & 1.86 & 1.037 & .221 & & Equal variances not assumed & & & 1.108 & 43.073 & .274 & .315 & .284 & -.258 & .888 \\
\hline Yes (Group A) & 28 & 1.75 & .887 & .168 & Obey codes and regulations & Equal variances assumed & .364 & .549 & .761 & 48 & .450 & .205 & .269 & -.336 & .745 \\
\hline No (Group B) & 22 & 1.55 & 1.011 & .215 & & Equal variances not assumed & & & .749 & 42.115 & .458 & .205 & .273 & -.346 & .756 \\
\hline Yes (Group A) & 28 & 1.54 & .881 & .167 & Cost estimation & Equal variances assumed & 18.213 & .000 & 2.266 & 48 & .028 & .445 & 196 & .050 & .839 \\
\hline No (Group B) & 22 & 1.09 & .294 & .063 & & Equal variances not assumed & & & 2.500 & 34.319 & .017 & .445 & 178 & .083 & .806 \\
\hline Yes (Group A) & 28 & 1.54 & .744 & 141 & Comply facility management & Equal variances assumed & 20.777 & .000 & 2.640 & 48 & .011 & .445 & 168 & .106 & .784 \\
\hline No (Group B) & 22 & 1.09 & .294 & .063 & & Equal variances not assumed & & & 2.888 & 36.927 & .006 & .445 & .154 & .133 & .757 \\
\hline Yes (Group A) & 28 & 1.43 & .634 & .120 & Lifecycle assessment & Equal variances assumed & 76.220 & .000 & 3.163 & 48 & .003 & .429 & .135 & .156 & .701 \\
\hline No (Group B) & 22 & 1.00 & .000 & .000 & & Equal variances not assumed & & & 3.576 & 27.000 & .001 & .429 & .120 & .183 & .674 \\
\hline Yes (Group A) & 28 & 1.21 & .630 & .119 & Sourcing (supply chain) & Equal variances assumed & 11.505 & .001 & 1.592 & 48 & .118 & .214 & .135 & -.056 & .485 \\
\hline No (Group B) & 22 & 1.00 & .000 & .000 & & Equal variances not assumed & & & 1.800 & 27.000 & .083 & .214 & .119 & -.030 & .459 \\
\hline
\end{tabular}

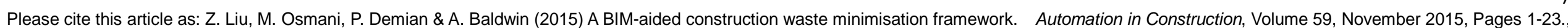
http://dx.doi.org/10.1016/j.autcon.2015.07.020 

in Construction, Volume 59, November 2015, Pages 1-23.

The interview participants further described their use of BIM for these activities. They reported that BIM is generally implemented throughout each design stage to generate the 3D model set, including the shared 3D model (common model), which is associated with 3D parametric modelling, as shown in Fig. 2.

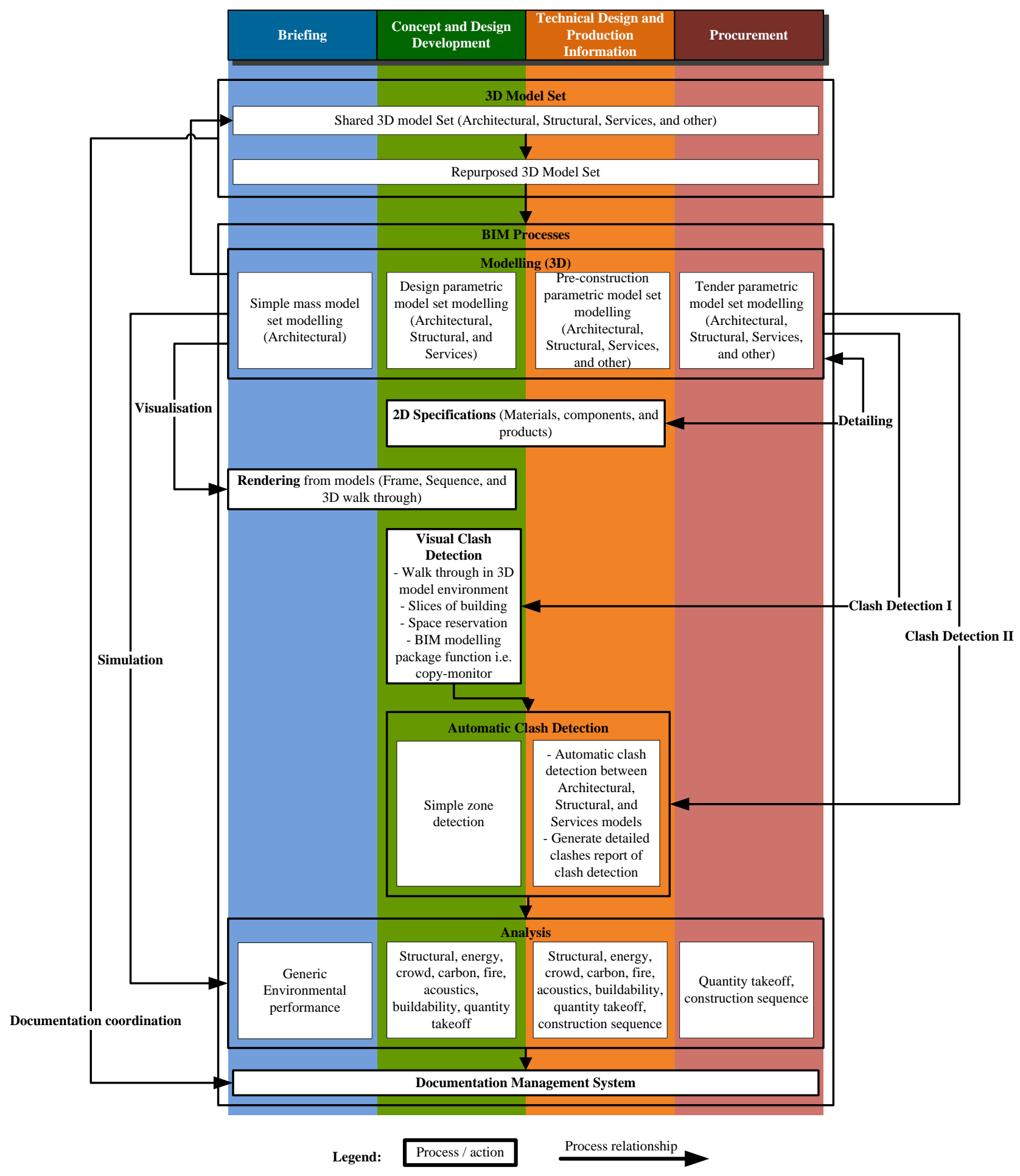

Fig. 2. Current use of BIM in building design (structured and arranged based on interviewees' responses)

The interviewees reported that the use of BIM in their current projects is important in terms of maintaining a high quality of design and providing insights into positive impacts of the activities on on-site construction waste generation, as shown in 
Z. Liu, M. Osmani, P. Demian \& A. Baldwin (2015) A BIM-aided construction waste minimisation framework. Automation in Construction, Volume 59, November 2015, Pages 1-23.

Table 2.

Table 2. The potential impact of BIM on construction waste minimisation (interviewees' responses)

\begin{tabular}{|c|c|}
\hline The use of BIM & Potential impact on construction waste minimisation \\
\hline \multirow{4}{*}{ BIM for detailing } & $\begin{array}{l}\text { Better understanding of design by clients through a detailed building } \\
\text { model resulting in fewer design changes }\end{array}$ \\
\hline & Getting level of detail (LOD) right leading to less on-site waste \\
\hline & More detail, clash detection and fewer on-site clashes \\
\hline & Better detailing coordination and specification leading to less re-work \\
\hline \multirow{3}{*}{ Clash detection through BIM } & Better coordinated design resulting in less on-site waste \\
\hline & Fewer clashes leading to less on-site waste \\
\hline & Less re-work and re-design resulting in less on-site waste \\
\hline \multirow{3}{*}{$\begin{array}{l}\text { Visualisation and simulation } \\
\text { within BIM }\end{array}$} & $\begin{array}{l}\text { Earlier understanding of the design by the client to avoid subsequent } \\
\text { on-site design changes }\end{array}$ \\
\hline & $\begin{array}{l}\text { Better understanding of the building by contractors and a visualised and } \\
\text { simulated construction process to lead to less on-site waste }\end{array}$ \\
\hline & $\begin{array}{l}\text { Enhanced communication and collaboration design between the design } \\
\text { team members to eliminate uncoordinated design resulting in fewer } \\
\text { clashes on-site }\end{array}$ \\
\hline $\begin{array}{l}\text { Improved coordination and } \\
\text { communication through BIM }\end{array}$ & $\begin{array}{l}\text { Effective and efficient multi-disciplinary design leading to less on-site } \\
\text { waste }\end{array}$ \\
\hline
\end{tabular}

\subsection{BIM potential to address construction waste causes}

The questionnaire respondents were asked to rate the potential impact of BIM to address construction waste causes during building design, using a scale of 1-4 (1=no potential, 2=low potential, 3=significant potential, 4=high potential). The results are shown in Table 3, which suggest that BIM can potentially have a high impact on addressing construction waste causes that are associated with design changes, design and detailing complexity, and ineffective coordination and communication at three levels: design team level, project level, and company level. In addition, the mean scores of Group A and Group B responses on the potential of using BIM to address waste causes during design are statistically similar, where all of the Sig. (2-Tailed) values in the Independent Samples T-test for Equality of Means between the two groups are greater than 0.05 , as shown in Table 3. 
Table 3. BIM potential to address construction waste causes during building design (questionnaire's responses)

\begin{tabular}{|c|c|c|c|c|c|c|c|c|c|c|c|c|c|c|c|}
\hline \multirow{4}{*}{$\begin{array}{c}\text { Groups of the } \\
\text { Use of BIM } \\
\text { for } \\
\text { Sustainable } \\
\text { Building } \\
\text { Design (SBD) } \\
\text { Strategies }\end{array}$} & \multicolumn{4}{|c|}{ Group Statistics } & & \multicolumn{10}{|c|}{ Independent Samples Test } \\
\hline & \multirow[t]{3}{*}{$\mathbf{N}$} & \multirow[t]{3}{*}{ Mean } & \multirow[t]{3}{*}{$\begin{array}{c}\text { Std. } \\
\text { Deviation }\end{array}$} & \multirow[t]{3}{*}{$\begin{array}{l}\text { Std. } \\
\text { Error } \\
\text { Mean }\end{array}$} & \multirow{3}{*}{$\begin{array}{c}\text { Construction Waste Causes During } \\
\text { Building Design }\end{array}$} & \multirow[t]{3}{*}{ Equal Variances Assumption } & \multicolumn{2}{|c|}{$\begin{array}{c}\text { Levene's Test } \\
\text { for Equality of } \\
\text { Variances } \\
\end{array}$} & \multicolumn{7}{|c|}{ t-test for Equality of Means } \\
\hline & & & & & & & \multirow[t]{2}{*}{$\mathrm{F}$} & \multirow[t]{2}{*}{ Sig. } & \multirow[t]{2}{*}{$\mathrm{t}$} & \multirow[t]{2}{*}{ df } & \multirow[t]{2}{*}{$\begin{array}{c}\text { Sig. } \\
\text { (2-tailed) }\end{array}$} & \multirow[t]{2}{*}{$\begin{array}{c}\text { Mean } \\
\text { Difference }\end{array}$} & \multirow[t]{2}{*}{$\begin{array}{l}\text { Std. Error } \\
\text { Difference }\end{array}$} & \multicolumn{2}{|c|}{$\begin{array}{c}95 \% \\
\text { Confidence } \\
\text { Interval of the } \\
\text { Difference } \\
\end{array}$} \\
\hline & & & & & & & & & & & & & & Lower & Upper \\
\hline Yes (Group A) & 28 & 3.11 & 1.100 & .208 & $\begin{array}{l}\text { Ineffective coordination and communication at } \\
\text { design team level }\end{array}$ & Equal variances assumed & .008 & .930 & .334 & 48 & .739 & .107 & .320 & -.537 & .751 \\
\hline No (Group B) & 22 & 3.00 & 1.155 & .246 & & Equal variances not assumed & & & .333 & 44.164 & .741 & .107 & .322 & -.542 & .756 \\
\hline Yes (Group A) & 28 & 3.04 & .962 & .182 & Design changes & Equal variances assumed & 2.299 & .136 & .732 & 48 & .468 & .218 & .297 & -.380 & .815 \\
\hline No (Group B) & 22 & 2.82 & 1.140 & .243 & & Equal variances not assumed & & & .717 & 41.070 & .477 & .218 & .303 & -.395 & .830 \\
\hline Yes (Group A) & 28 & 3.00 & 1.054 & .199 & $\begin{array}{l}\text { Ineffective coordination and communication at } \\
\text { project level }\end{array}$ & Equal variances assumed & .689 & .411 & .291 & 48 & .773 & .091 & .313 & -.538 & .720 \\
\hline No (Group B) & 22 & 2.91 & 1.151 & .245 & & Equal variances not assumed & & & .288 & 43.205 & .775 & .091 & .316 & -.546 & .728 \\
\hline Yes (Group A) & 28 & 2.75 & 1.041 & .197 & Design and detailing complexity & Equal variances assumed & .015 & .903 & .230 & 48 & .819 & .068 & .297 & -.528 & .665 \\
\hline No (Group B) & 22 & 2.68 & 1.041 & .222 & & Equal variances not assumed & & & .230 & 45.231 & .819 & .068 & .297 & -.529 & .666 \\
\hline Yes (Group A) & 28 & 2.71 & .976 & .184 & Design and construction detail errors & Equal variances assumed & .000 & .992 & .116 & 48 & .908 & .032 & .280 & -.531 & .596 \\
\hline No (Group B) & 22 & 2.68 & .995 & .212 & & Equal variances not assumed & & & .116 & 44.834 & .909 & .032 & .281 & -.534 & .599 \\
\hline Yes (Group A) & 28 & 2.64 & 1.062 & .201 & $\begin{array}{l}\text { Ineffective coordination and communication at } \\
\text { company level }\end{array}$ & Equal variances assumed & .639 & .428 & -.268 & 48 & .790 & -.084 & .315 & -.718 & .550 \\
\hline No (Group B) & 22 & 2.73 & 1.162 & .248 & & Equal variances not assumed & & & -.265 & 43.140 & .792 & -.084 & .319 & -.727 & .558 \\
\hline Yes (Group A) & 28 & 2.29 & 1.049 & .198 & Specification flaws & Equal variances assumed & .047 & .829 & -.412 & 48 & .682 & -.123 & .299 & -.725 & .479 \\
\hline No (Group B) & 22 & 2.41 & 1.054 & .225 & & Equal variances not assumed & & & -.412 & 45.147 & .682 & -.123 & .300 & -.727 & .480 \\
\hline
\end{tabular}

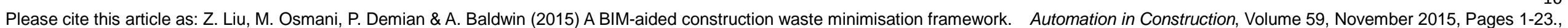
http://dx.doi.org/10.1016/j.autcon.2015.07.020 
There was consensus among the interviewed architects that ineffective CWM coordination and communication could be addressed through BIM-enhanced technical and document management methods at all three levels, as presented in Fig. 3. All interviewees agreed that coordination and communication could be more effective through sharing a coordinated 3D model, known as 'the common model', between disciplines at design team level (architect, structural engineer, and services engineer), project level (client, design team, and project partners), and company level (architectural practices). Half of the interviewees agreed that a coordinated 3D model should be a simple model in terms of sharing information between disciplines, and contractors should be involved during the early design stages to promote better constructability consideration in design. BIM would contribute to either improving communication of the early concept of building model components or addressing ineffective coordination of multi-disciplinary design to minimise construction waste. In addition, one third of the interviewees reported that clash detection has been implemented through BIM in their projects to overcome ineffective coordination and communication.

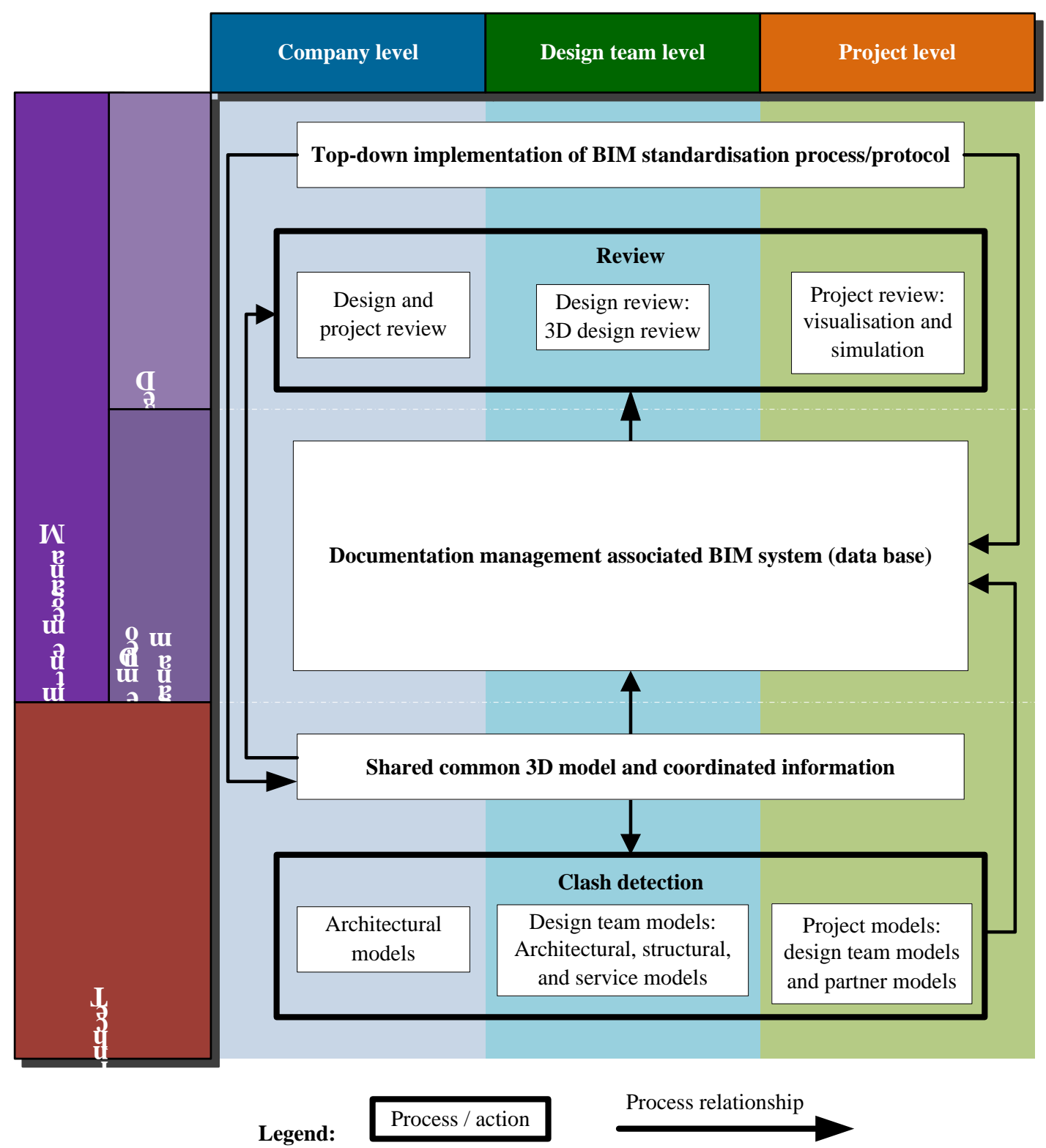

Fig. 3. BIM potential to address ineffective coordination and communication (structured and arranged based on interviewees' responses) 
The interviewees agreed that a BIM process using the right standard ensures effective coordination and communication between project team members during multi-disciplinary design. Half of the interviewees stressed that the top-down management structure for the standard BIM process implementation into a project is essential to enable effective CWM coordination and communication through multi-disciplinary BIM-focused design. Additionally, a third of the interviewees emphasised the importance of the design and project review process, which improves multi-disciplinary coordination and communication in order to locate the best opportunity for waste reduction. Furthermore, half the interviewees held the view that the use of a document management system-associated BIM database system, such as Newforma, strengthens management methods. On the other hand, coordination and communication through a shared 3D common model and design/project reviews can be enhanced by coordinated design documentation, which reduces waste caused by lack of coordination of detail design.

BIM was deemed to have a significant or major effect on addressing design changes by questionnaire respondents, as shown in Table 3. This was further explained by all interviewees who shared the view that design changes made by the client during site operations could be avoided through BIM-facilitated design. Three quarters of the interviewees went further by highlighting another benefit associated with the use of BIM to address client-led changes. They argued that 3D parametric modelling (model coordination and simulation within BIM) would allow designers to quickly establish changes that would impact upon the project by optimising the design in coordination with others. Similarly, one third of the interviewees suggested that the document management functionality associated with BIM for communication and coordination (Fig. 3) could help manage design changes efficiently during construction to reduce consequential construction waste during site operations.

\subsection{BIM potential for construction waste minimisation throughout building design stages}

The questionnaire respondents were asked to rate the potential impact of BIM to address construction waste throughout each of the pre-construction RIBA Plan of Work stages from Appraisal to Tender Action using a scale of 1-4 (1=no potential, 2=low potential, 3=significant potential, 4=high potential). The results are shown in Table 4, where both Group $A$ and Group B architects acknowledged the promising potential impact of implementing BIM for CWM across most of the building design stages of the RIBA Plan of Work stages, excluding Tender Action, where the Tender Action's Sig. (2-Tailed) value in the Independent Samples T-test for Equality of Means between the two groups is equal to 0.05 . 


\begin{tabular}{|c|c|c|c|c|c|c|c|c|c|c|c|c|c|c|c|}
\hline \multirow{4}{*}{$\begin{array}{c}\text { Groups of } \\
\text { the Use of } \\
\text { BIM for } \\
\text { Sustainable } \\
\text { Building } \\
\text { Design (SBD) } \\
\text { Strategies }\end{array}$} & \multicolumn{4}{|c|}{ Group Statistics } & & \multicolumn{10}{|c|}{ Independent Samples Test } \\
\hline & \multirow[t]{3}{*}{$\mathbf{N}$} & \multirow[t]{3}{*}{ Mean } & \multirow[t]{3}{*}{$\begin{array}{c}\text { Std. } \\
\text { Deviation }\end{array}$} & \multirow[t]{3}{*}{$\begin{array}{l}\text { Std. } \\
\text { Error } \\
\text { Mean }\end{array}$} & \multirow[t]{3}{*}{ Building Design Stages } & \multirow[t]{3}{*}{ Equal Variances Assumption } & \multicolumn{2}{|c|}{$\begin{array}{l}\text { Levene's } \\
\text { Test for } \\
\text { Equality of } \\
\text { Variances } \\
\end{array}$} & \multicolumn{7}{|c|}{$\mathrm{t}$-test for Equality of Means } \\
\hline & & & & & & & \multirow[t]{2}{*}{$\mathrm{F}$} & \multirow[t]{2}{*}{ Sig. } & \multirow[t]{2}{*}{$\mathrm{t}$} & \multirow[t]{2}{*}{ df } & \multirow[t]{2}{*}{$\begin{array}{c}\text { Sig. } \\
\text { (2-tailed) }\end{array}$} & \multirow[t]{2}{*}{$\begin{array}{c}\text { Mean } \\
\text { Difference }\end{array}$} & \multirow[t]{2}{*}{$\begin{array}{l}\text { Std. Error } \\
\text { Difference }\end{array}$} & \multicolumn{2}{|c|}{$\begin{array}{c}95 \% \text { Confidence Interval of } \\
\text { the Difference }\end{array}$} \\
\hline & & & & & & & & & & & & & & Lower & Upper \\
\hline Yes (Group A) & 28 & 1.96 & 1.071 & .202 & Appraisal & Equal variances assumed & .208 & .651 & .188 & 48 & .851 & .055 & .293 & -.534 & .644 \\
\hline No (Group B) & 22 & 1.91 & .971 & .207 & & Equal variances not assumed & & & .191 & 46.954 & .850 & .055 & .290 & -.527 & .638 \\
\hline Yes (Group A) & 28 & 2.07 & 1.016 & .192 & Design Brief & Equal variances assumed & .011 & .916 & -.383 & 48 & .703 & -.110 & .288 & -.690 & .469 \\
\hline No (Group B) & 22 & 2.18 & 1.006 & .215 & & Equal variances not assumed & & & -.383 & 45.431 & .703 & -.110 & .288 & -.690 & .469 \\
\hline Yes (Group A) & 28 & 2.64 & 1.129 & .213 & Concept & Equal variances assumed & .714 & .402 & -.421 & 48 & .676 & -.130 & .309 & -.750 & .490 \\
\hline No (Group B) & 22 & 2.77 & 1.020 & .218 & & Equal variances not assumed & & & -.426 & 47.007 & .672 & -.130 & .305 & -.743 & .483 \\
\hline Yes (Group A) & 28 & 3.04 & 1.105 & .209 & Design Development & Equal variances assumed & .748 & .391 & -.185 & 48 & .854 & -.055 & .299 & -.656 & .545 \\
\hline No (Group B) & 22 & 3.09 & .971 & .207 & & Equal variances not assumed & & & -.188 & 47.344 & .852 & -.055 & .294 & -.647 & .536 \\
\hline Yes (Group A) & 28 & 2.96 & 1.071 & .202 & Technical Design & Equal variances assumed & .187 & .667 & .188 & 48 & .851 & .055 & .293 & -.534 & .644 \\
\hline No (Group B) & 22 & 2.91 & .971 & .207 & & Equal variances not assumed & & & .191 & 46.954 & .850 & .055 & .290 & -.527 & .638 \\
\hline Yes (Group A) & 28 & 2.96 & 1.105 & .209 & Production Information & Equal variances assumed & .730 & .397 & .185 & 48 & .854 & .055 & .299 & -.545 & .656 \\
\hline No (Group B) & 22 & 2.91 & .971 & .207 & & Equal variances not assumed & & & .188 & 47.344 & .852 & .055 & .294 & -.536 & .647 \\
\hline Yes (Group A) & 28 & 2.79 & 1.228 & .232 & Tender Documentation & Equal variances assumed & 5.302 & .026 & 1.623 & 48 & .111 & .513 & .316 & -.123 & 1.148 \\
\hline No (Group B) & 22 & 2.27 & .935 & .199 & & Equal variances not assumed & & & 1.677 & 47.968 & .100 & .513 & .306 & -.102 & 1.128 \\
\hline Yes (Group A) & 28 & 2.61 & 1.257 & .238 & Tender Action & Equal variances assumed & 10.615 & .002 & 1.927 & 48 & .060 & .607 & .315 & -.026 & 1.240 \\
\hline No (Group B) & 22 & 2.00 & .873 & .186 & & Equal variances not assumed & & & 2.012 & 47.368 & .050 & .607 & .302 & .000 & 1.214 \\
\hline
\end{tabular}


Z. Liu, M. Osmani, P. Demian \& A. Baldwin (2015) A BIM-aided construction waste minimisation framework. Automation in Construction, Volume 59, November 2015, Pages 1-23.

The questionnaire results revealed that BIM was not frequently used in building design in general and for CWM in particular, where only 28 out of 50 responding architects (all Group A respondents) had used BIM for sustainable building design. However, there was agreement between Group A and B respondents that BIM has great potential to facilitate waste minimisation. Moreover, the Concept, Design Development, Technical Design and Production Information stages were thought by both responding groups to be the phases where BIM had the most significant potential to minimise waste than other stages, as shown in Table 4.

Two thirds of the interview-participating architects held the view that BIM has the potential to minimise construction waste throughout the Briefing stages (Appraisal and Design Brief) through visualisation and simulation allowing for better communication with the client; fitting the high-level sustainability needs of the client, including feasibility studies; and assisting with decision making for strategic brief development. About half of the interviewees commented that high-level sustainability studies have an impact on CWM in terms of seeking opportunities to minimise construction waste and capturing sustainability needs of the client. Nearly one third of the interviewees further suggested that the management setup plan for BIM is critical to enable high-level sustainability studies in order to communicate the findings to clients. On the other hand, a fifth of the interviewees argued that the potential to minimise waste through BIM at Briefing stages is limited, because the design is loose at this stage. This may explain why the mean values of potential impact of implementing BIM for CWM during the Briefing stages of both responding Group A and Group B architects in the questionnaire results are close to 2.0, which is low potential, as shown in Table 4.

Four fifths of the interviewees strongly agreed that the Concept and Design Development stages offer the greatest opportunities to minimise waste through BIM. They suggested that during the latter stages, BIM could help minimise construction waste by assisting early design decisions to prepare and develop design concepts through 3D parametric modelling, shared 3D common model enhanced coordination and communication, clash detection, and visualisation and simulation. As such, architects could make waste-related decisions earlier through a BIM platform. One fifth of the interviewees agreed that the project brief could be developed efficiently by using BIM for energy efficiency to subsequently influence the development of waste minimisation. However, the uniqueness of design creativity during the Concept stage is important to the building design so that it may harm the CWM through BIM, as one of the interviewees argued that architects dislike to be limited in concept design by BIM modelling in terms of waste minimisation, which could explain why the mean values of potential impact of implementing BIM for CWM in the stage of both responding groups within the questionnaire results are less than 3.0, as shown in Table 4.

All interviewees made it clear that the potential of using BIM to facilitate CWM throughout the Technical Design and Production Information stages could potentially facilitate technical design decision making and production information by detailed modelling and coordination, efficient specification of material, improved communication and collaboration, and simulation. Nearly three quarters of the interviewees emphasised that the use of BIM allows designers to produce coordinated construction details, enabling them to assess the impact of design decisions on construction outputs through simulation. Nearly half of the interviewees suggested that detailed model coordination (for Technical Design and Production Information between designers and the main contractor, sub-contractors, and specialist contractors) is key to effective CWM coordination and communication. Importantly, a third of the interviewees stressed that clash detection for detailed model coordination eliminates design and construction detail errors, which in turn minimises waste. Furthermore, half of the interviewees argued that material and product specification through BIM could influence construction waste reduction performance. As such, specification links the information to materials and components on the market through BIM, which helps predict waste performance targets. However, in some cases, the nature of the building design project (where designer-led development of the BIM model will end at the end of the Design Development stage when the client signs off the contract) could negatively affect the impact of implementing BIM for CWM during the Technical Design and Production Information stages. As such, the ownership of the detailed and coordinated BIM model during these stages should be allocated to the lead designer rather than the contractor in terms of coordination with the construction model, to 
Z. Liu, M. Osmani, P. Demian \& A. Baldwin (2015) A BIM-aided construction waste minimisation framework. Automation in Construction, Volume 59, November 2015, Pages 1-23.

minimise waste influenced by design because, as an interviewee suggested, the as-designed model owned by the lead designer can always affect the construction model during construction.

\section{BIM-aided construction waste minimisation (BaW) Framework development}

The rationale of the BaW Framework was to use BIM as a vehicle to assist with CWM decision making during building design. The development of the BaW Framework was based on key findings from the literature review, questionnaire and interview results, as shown in Fig. 4, to address construction waste causes (Table 5) throughout building design stages. The Concept and Design Development stages were identified from the questionnaire and interview results as the stages where BIM had the most potential for CWM.

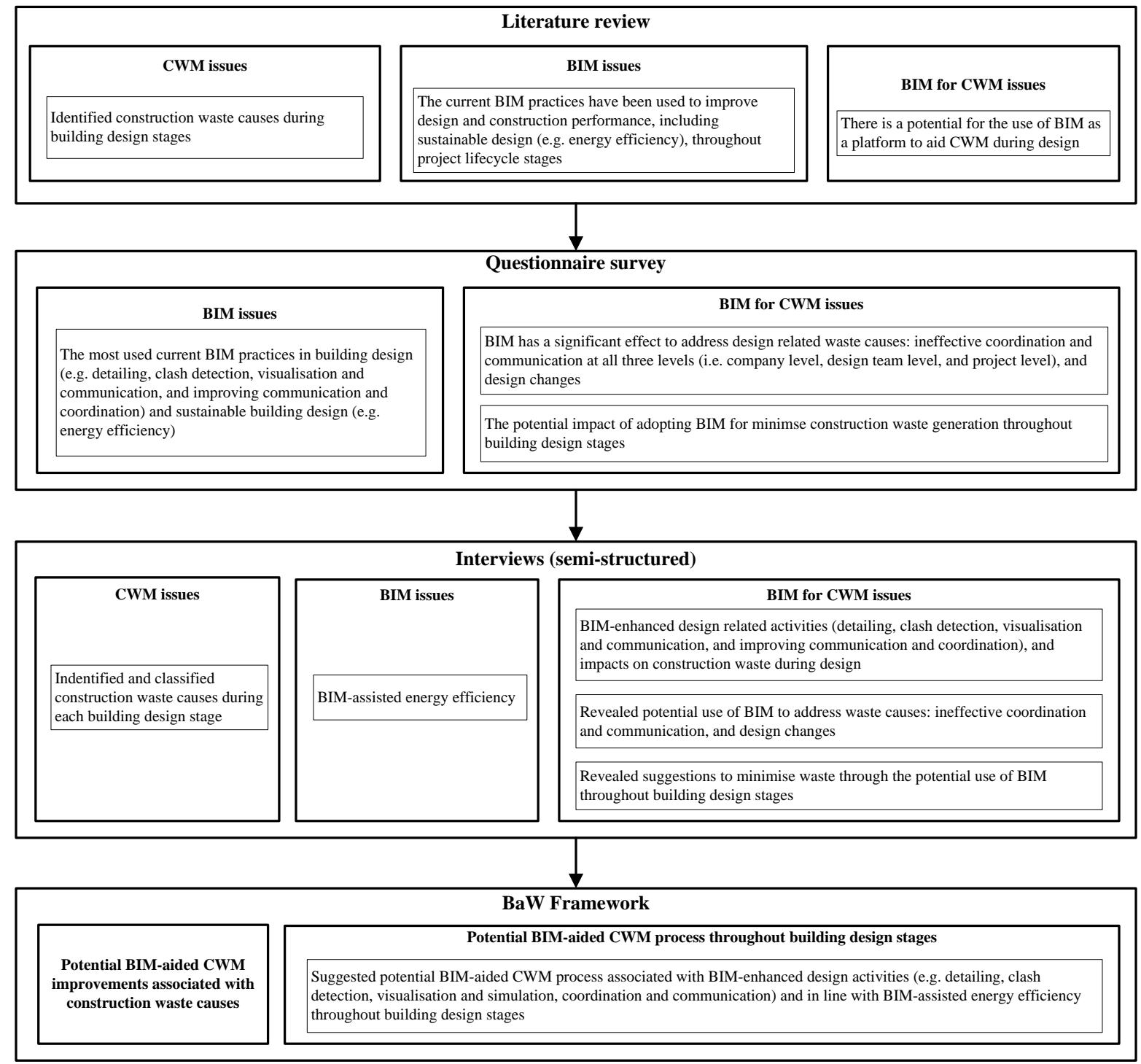

Fig. 4. The BaW Framework design and development flow chart

The BaW Framework includes two levels: a strategic High-level Framework and a detailed Low-level Framework with two associated evaluation process components, as shown in Fig. 5. The BaW Framework levels comprise process actions representing key improvements to minimise design-related construction waste and a coding system. 

in Construction, Volume 59, November 2015, Pages 1-23.

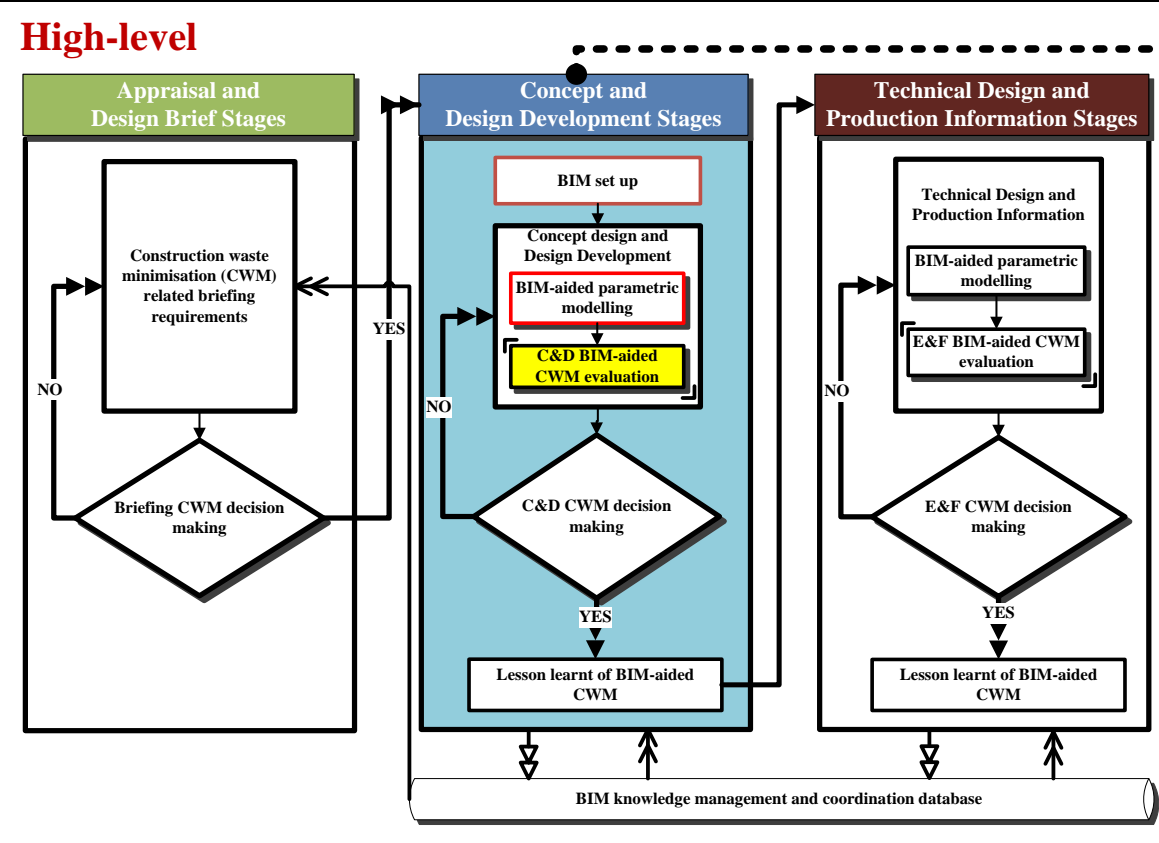

Low-level
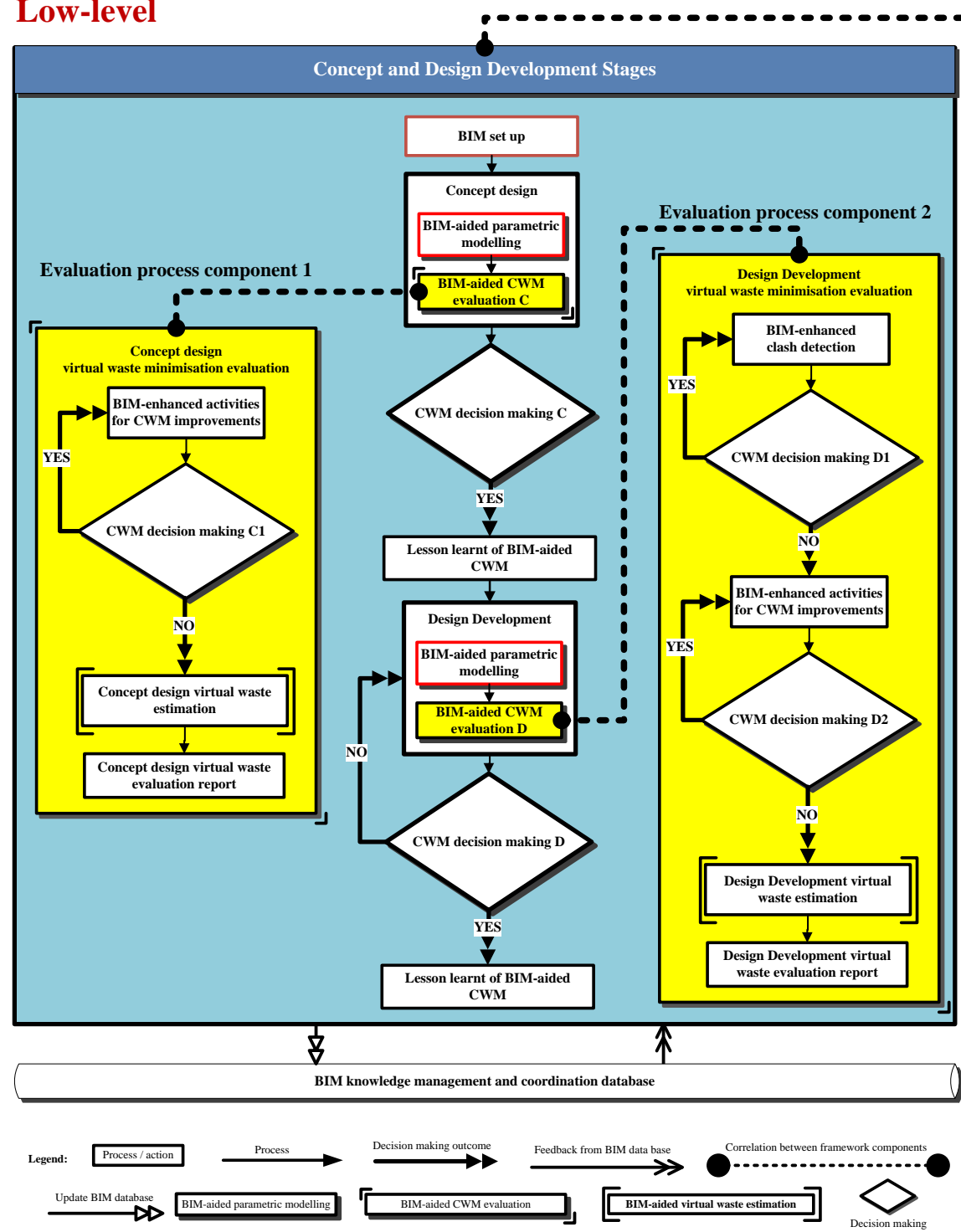

Keys: C (Concept stage); D (Design Development stage); E (Technical Design stage); F (Production Information stage) 
Z. Liu, M. Osmani, P. Demian \& A. Baldwin (2015) A BIM-aided construction waste minimisation framework. Automation in Construction, Volume 59, November 2015, Pages 1-23.

\section{Fig. 5. Dependency between BaW Framework levels}

\subsection{High-level BIM-aided construction waste minimisation (BaW) Framework}

The High-level BaW Framework, as shown in Fig. 6, presents the strategic use of BIM-aided CWM decision making across all building design stages. The BaW Framework comprises BIM-enhanced activities to address design-related construction waste causes in each coded component. The design-related waste causes, which were identified from the literature review and interviews, are listed in Table 5. The High-level BaW Framework contains three grouped design stages: Appraisal and Design Brief; Concept and Design Development; and Technical Design and Production Information. 

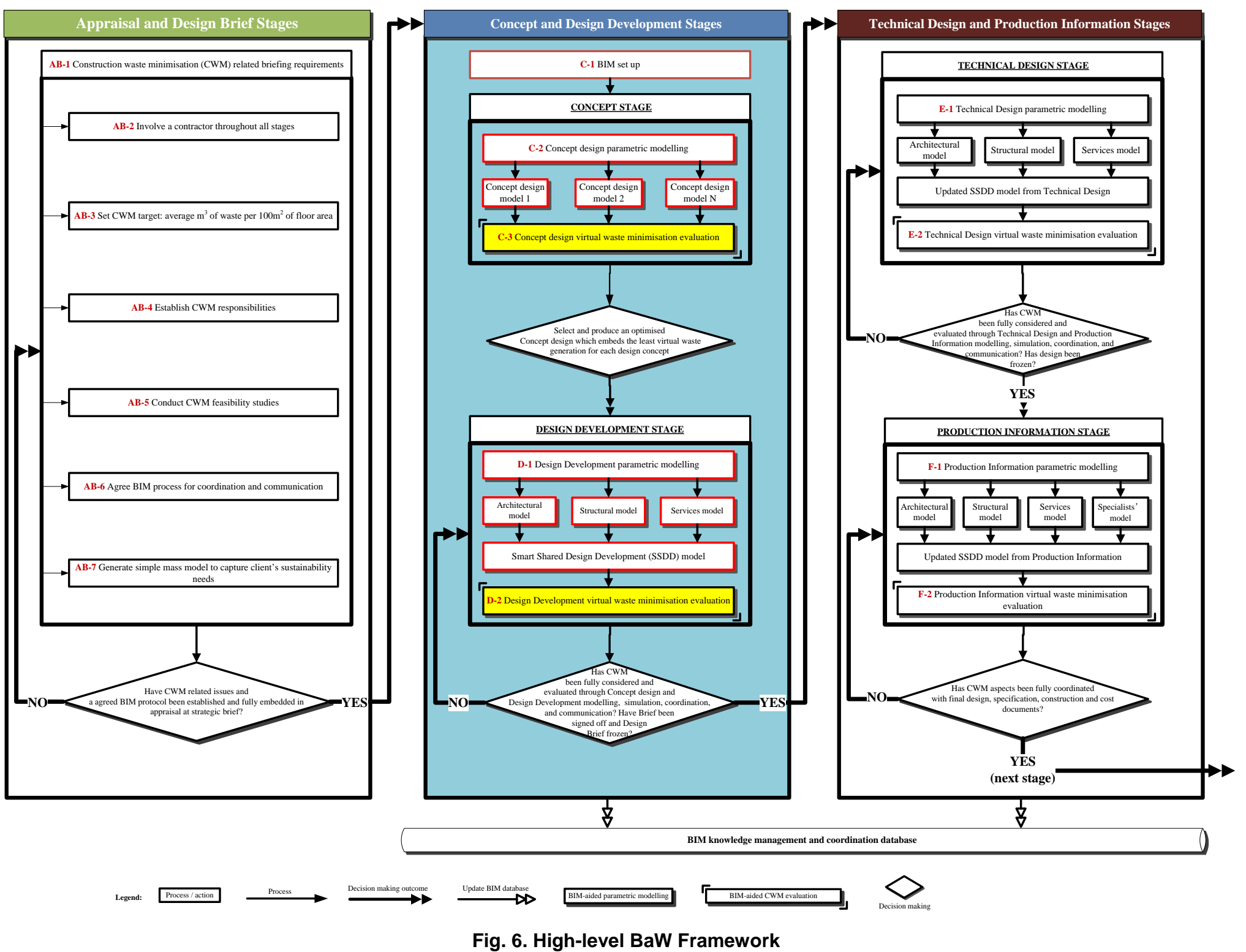
Table 5. Addressing construction waste causes throughout building design stages in the BIM-aided construction waste minimisation (BaW) Framework

\begin{tabular}{|c|c|c|}
\hline Stages & Construction Waste Causes & $\begin{array}{l}\text { BIM-aided CWM (BaW) Framework } \\
\text { contents }\end{array}$ \\
\hline \multirow{6}{*}{$\begin{array}{l}\text { Appraisal \& } \\
\text { Design Brief }\end{array}$} & Lack of early involvement by contractor $[7,58,60]$ & $A B-2$ \\
\hline & Lack of clear goal for waste minimisation $[59,61]$ & AB-3 \\
\hline & Lack of waste responsibility $[7,59]$ & AB-4 \\
\hline & Lack of waste feasibility studies $[58,59,60]$ & $A B-5$ \\
\hline & Ineffective coordination and communication $[3,7,24,27,28,43,58,59,60,61,63,72]$ & AB-6 \\
\hline & Failure to identify client needs $[52,72]$ & $A B-7$ \\
\hline \multirow{5}{*}{$\begin{array}{l}\text { Concept Design \& Design } \\
\text { Development }\end{array}$} & Ineffective coordination and communication $[3,7,24,27,28,43,58,59,60,61,63,72]$ & C-1, C-3, D-2 \\
\hline & Difficulties with design complexity coordination $[3,43,58,60,63]$ & C-2, D-1 \\
\hline & Design changes $[3,7,24,27,28,58,60,61,62]$ & C-3, D-2 \\
\hline & Unclear outline specification of material purpose $[3,7,24,58,60,62]$ & C-3, D-2 \\
\hline & Lack of attention paid to dimensional coordination $\quad[27,28,60,74,81]$ & C-3, D-2 \\
\hline \multirow{4}{*}{$\begin{array}{l}\text { Technical Design \& } \\
\text { Production Information }\end{array}$} & Design and construction detail errors $[3,7,24,27,28,60,61]$ & $E-1, E-2, F-1, F-2$ \\
\hline & Ineffective coordination and communication $[3,7,24,27,28,43,58,59,60,61,63,72]$ & $\mathrm{E}-2, \mathrm{~F}-2$ \\
\hline & Unclear specification of material, products and components $[3,7,24,58,60,62]$ & $\mathrm{E}-2, \mathrm{~F}-2$ \\
\hline & $\begin{array}{l}\text { Not fully evaluated design leads to design changes during construction period (design decision) }[3,7,24,27,28 \text {, } \\
58,60,61,62]\end{array}$ & $\mathrm{E}-2, \mathrm{~F}-2$ \\
\hline
\end{tabular}



in Construction, Volume 59, November 2015, Pages 1-23.

\subsubsection{Appraisal and Design Brief stages}

Six specific CWM improvements related to briefing requirements are indicated during the Appraisal and Design Brief stages, as shown in Fig. 6. These improvements are designed to address waste causes, as listed in Table 5, such as early contractor involvement, CWM target setting, CWM responsibilities establishment, conducting CWM feasibility studies, agreement of BIM process for effective coordination and communication, and creating simple mass model for capturing the client's sustainability needs. These improvements ensure that CWM-related issues and an agreed BIM process would be established and fully embedded in the Appraisal and Design Brief stages.

\subsubsection{Concept and Design Development stages}

The results of the interview indicated that the process of using BIM could assist CWM decision making at the Concept and Design Development stages through parametric modelling-enhanced CWM coordination and communication. As illustrated in Fig. 5 and Fig. 6, processes of BIM-aided CWM decision making during the Concept and Design Development stages are facilitated by BIM setup, parametric modelling, and waste minimisation evaluation. These improvements are associated with the identified construction waste causes in Table 5. The proposed BIM database provides BIM-aided CWM knowledge management and a platform for enhancing coordination and communication.

\subsubsection{Technical Design and Production Information stages}

The interview results revealed that the potential use of BIM to aid CWM during the Technical Design and Production Information stages is to facilitate CWM decision making, in terms of detailing, specification, and scheduling. This is achieved through a number of design activities within the BIM-enhanced environment. These activities include detailed modelling and coordination, efficient specification of material, improved coordination and communication, and simulation. Furthermore, the interview results suggested that coordination of the detailed 3D parametric model, which is produced from a BIM-enhanced material and product specification detailing process, is key to the decision making that can have a great impact on CWM in terms of 'level of detail (LOD)' for a better understanding of the relationship between design and construction. The BIM process includes Technical Design and Production Information parametric modelling that aims to update and coordinate architectural, structural, and services models from the Design Development stage, along with models from contactors and sub-contractors for creation and subsequent updating of the Smart Shared Design Development (SSDD) model of Technical Design and Production information. This in turn facilitates the Technical Design and Production Information virtual waste minimisation evaluation process to minimise construction waste during design.

\subsection{Low-level BIM-aided construction waste minimisation (BaW) Framework}

The BaW Low-level Framework contains a detailed BIM-aided CWM process and correlated actions during the Concept and Design Development stages, as shown in Fig. 7. 
Z. Liu, M. Osmani, P. Demian \& A. Baldwin (2015) A BIM-aided construction waste minimisation framework. Automation in Construction, Volume 59, November 2015, Pages 1-23.

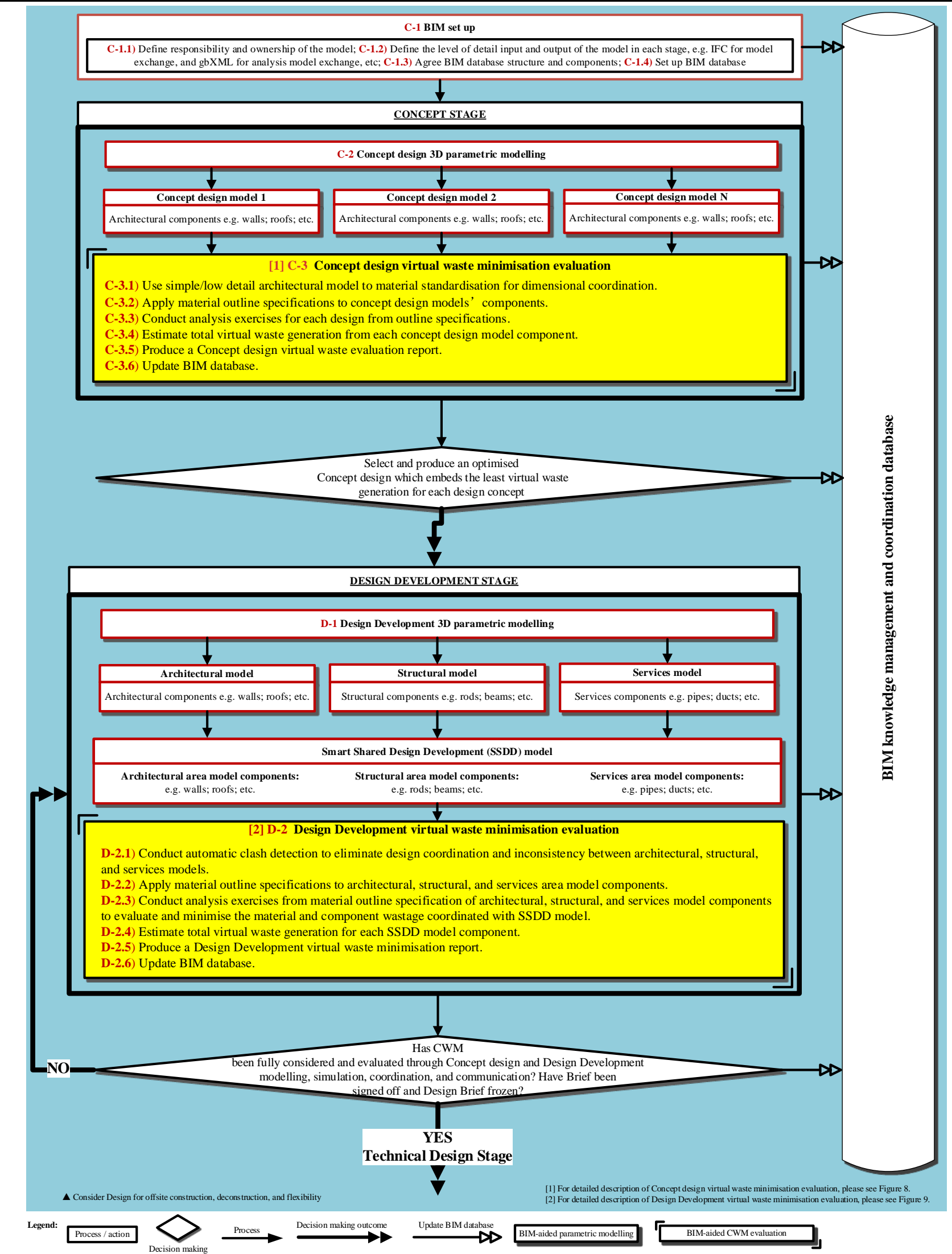

Fig. 7. Low-level BaW Framework

The interview results suggested that CWM could be improved through four BIM-enhanced design-related activities during 
the preparation and development of design concepts: improved coordination and communication, visualisation and simulation, detailing, and clash detection. These BIM-driven design activities could be used to address coordination and communication-related construction waste causes (Table 5), such as design changes, lack of attention paid to dimensional coordination in design, design complexity and material specification, and unclear specification of material.

\subsubsection{Low-level BaW Framework Concept design and associated evaluation process}

\subsubsection{Low-level BaW Framework Concept design}

Prior to the commencement of the Concept stage, the initial BIM setup should be established as the basis for effective coordination and communication through three main activities: defining responsibility and ownership of the model, defining the LOD input and output of the model during each design stage, and agreeing on a project BIM database structure and components, as shown in Fig. 7.

The interview results indicated that design decisions not fully evaluated during the Concept and Design Development stages are most likely to trigger design changes during construction. This is also accentuated by ineffective coordination and communication, including failure to identify the needs of the client, which causes on-site client-led design changes. The BIM-associated design activities are intended to minimise construction waste during the design process. This ensures better decision making for selecting and producing an optimised concept design that embeds the least 'virtual' waste generation for each design concept upon completion of the Concept stage. The process involves Concept design 3D parametric modelling to address difficulties in resolving design issues of architectural complexity when creating various concept design models; and Concept design 'virtual' waste minimisation evaluation. Architectural components, such as walls and roofing, are created by implementing 3D parametric modelling techniques for each model design concept. Subsequently, each concept design model will be evaluated to assess its 'virtual' waste minimisation performance. The BaW Low-level Framework component related to the evaluation of Concept design virtual waste minimisation is discussed below.

\subsubsection{Low-level BaW Framework Concept design evaluation process}

Architectural components of each concept design model are generated through the use of a low-detailed architectural model to check material standardisation for dimensional coordination. Based on these architectural components, material outline specifications can be applied to the components in each concept design model via five specific steps, whereby component material thicknesses are identified. These steps are locating component layer, creating material for layer, creating material surface pattern in line with outline material specification, setting the material surface pattern repeat, and assigning the material to the component layer. These are in turn followed by two steps of qualitative analysis exercises by means of visualisation from outline specifications, as shown in Fig. 8. Such qualitative construction waste analysis exercises are conducted to ensure model components or material outline specifications are reviewed to satisfy minimisation of waste surface areas for the quantitative estimation of total virtual waste generation from each concept design model. 


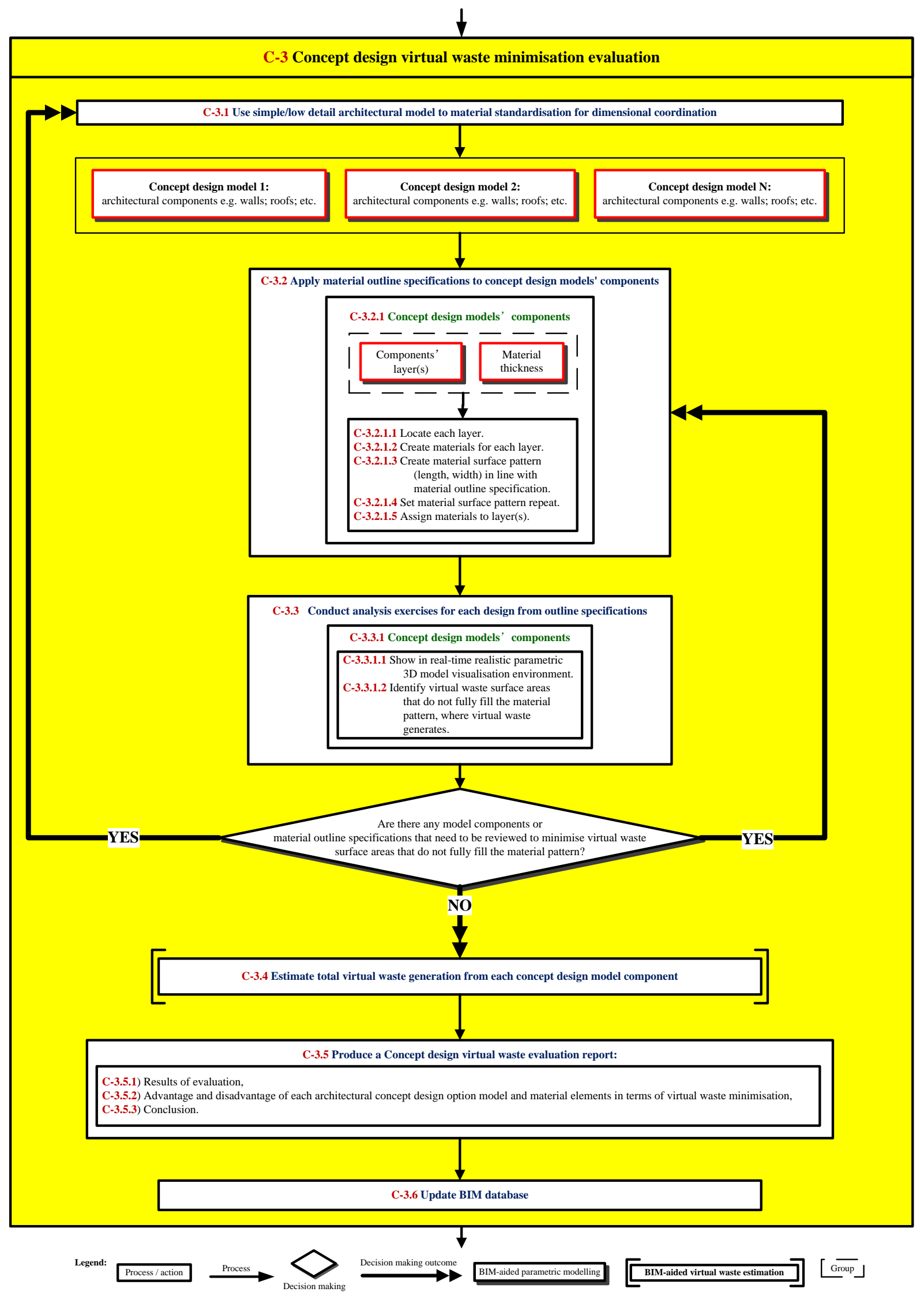

Fig. 8. Low-level BaW Framework Concept design evaluation process component 
Hence, each design concept is integrated into the model for visualisation and quantity takeoff to assist the architect working with the total virtual waste analysis. The process of estimating the total virtual waste generation for each design concept model (1 to $\mathrm{N}$ ) component (C-3.4 in Fig. 8) is to calculate waste volume in line with the CWM target in the High-level Framework. For example, the steps of estimating the total virtual waste generation for concept design model 1 component are as follows:

1) Calculate virtual waste CA1: (Concept) Area 1 (surface area $\left(\mathrm{m}^{2}\right)$ of each virtual waste in each concept design model 1 component)

2) Use virtual waste (Concept) СT1 (unit thickness $(m)$ of each virtual waste surface area in each concept design model 1 component) from material outline specification (data takeoff from Concept Design models' components (C-3.2.1 in Fig. 8))

3) Calculate virtual waste CV1: (Concept) Volume 1 (virtual waste volume $\left(\mathrm{m}^{3}\right)$ of each virtual waste in each concept design model 1 component) by using CV1 = CA1 $\times$ CT1

4) Calculate (Concept) VC1 (total virtual waste volume $\left(\mathrm{m}^{3}\right)$ of each concept design model 1 component) by using

$$
\mathrm{VC1}=\sum_{i=1}^{n} \operatorname{CV} 1 i
$$

5) Calculate (Concept) SVC1: Sum of all concept design model 1 virtual waste volume $\left(\mathrm{m}^{3}\right)$ (all concept design model 1 components) by using

$$
\operatorname{SVC1}=\sum_{i=1}^{n} \mathrm{VC1} i
$$

6) Takeoff area quantity of each floor in concept design model 1 to calculate the (Concept) CAf1 (total floor area ( $\mathbf{m}^{2}$ ) in concept design model 1) by automatic area quantity takeoff schedule calculation (data takeoff from architectural model (C-3.1 in Fig. 8))

7) Calculate (Concept) Area Rate of Virtual Waste (CRvw) $\left(\mathrm{m}^{3}\right.$ per $\left.\mathbf{m}^{2}\right)$ of concept design model 1 by using CRvw1 = SVC1 $/$ CAf1

Subsequently, a report on Concept design 'virtual' waste evaluation is produced based on the evaluation results for decision making to select the Concept design that generates the least 'virtual' waste.

Based upon the results of these models, BIM-aided CWM improvements would address design-related waste causes, as shown in Table 6. 
Table 6. BIM-aided CWM improvements to construction waste causes during the Concept and Design Development stages

\begin{tabular}{|c|c|c|}
\hline & $\begin{array}{l}\text { Construction waste } \\
\text { causes }\end{array}$ & BIM-aided CWM improvements \\
\hline \multirow{4}{*}{ 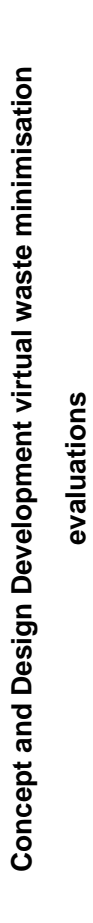 } & $\begin{array}{l}\text { Not fully evaluated } \\
\text { design leads to design } \\
\text { changes during } \\
\text { construction period } \\
\text { (design decision) }\end{array}$ & $\begin{array}{ll}\text { - } & \text { Concept Design virtual waste minimisation evaluation } \\
\text { - } & \text { Design Development virtual waste minimisation evaluation }\end{array}$ \\
\hline & $\begin{array}{l}\text { Ineffective coordination } \\
\text { and communication }\end{array}$ & $\begin{array}{l}\text { - Conduct automatic clash detection to eliminate design coordination } \\
\text { and inconsistency between architectural, structural, and services } \\
\text { models } \\
\text { - } \quad \text { Produce a Concept Design virtual waste evaluation report } \\
\text { - } \quad \text { Produce a Design Development virtual waste minimisation report } \\
\text { - } \quad \text { Update BIM database }\end{array}$ \\
\hline & $\begin{array}{l}\text { Unclear outline } \\
\text { specification of material } \\
\text { purpose }\end{array}$ & $\begin{array}{l}\text { - Apply material outline specifications to Concept design model } \\
\text { components } \\
\text { - Apply material outline specifications to architectural, structural, and } \\
\text { services area model components }\end{array}$ \\
\hline & $\begin{array}{l}\text { Lack of attention paid to } \\
\text { dimensional coordination }\end{array}$ & $\begin{array}{l}\text { Use simple/low detail architectural model to material standardisation for } \\
\text { dimensional coordination }\end{array}$ \\
\hline
\end{tabular}

Related information to the BIM-facilitated Concept design process is uploaded to the BIM knowledge database for continuous knowledge capture and information management, which is used to enhance CWM communication.

The selected and optimised architectural model that generates minimum 'virtual' waste from the Concept stage would be used and further developed during the Design Development in partnership with other design team members. This facilitates collaborative design team decision making, which ensures that CWM has been fully considered and evaluated through modelling, simulation, coordination and communication. The results of the decision making process would also help sign off and freeze the Design Brief.

\subsubsection{Low-level BaW Framework Design Development and associated evaluation process}

\subsubsection{Low-level BaW Framework Design Development}

Design Development 3D parametric modelling is used to resolve design issues of architectural, structural, and services design complexity. It merges multi-disciplinary models from the architectural design, structural design, and services design into a coordinated SSDD model. This is used for Design Development 'virtual' waste minimisation evaluation to address design-related construction waste causes, as shown in Table 6.

The separate structural and services models are based on the architectural model, which has been updated from the selected and optimised Concept Design model. All the model's components are constructed through the use of 3D parametric modelling techniques, which keep changes predictable and coordinated during the design process. All three models are assembled as an SSDD model which contains architectural, structural, and services model component. On the basis of the SSDD model, the BaW Low-level Framework comprises six actions for the evaluation of 'virtual' waste minimisation during the Design Development stage, as shown in Fig. 7. These actions are discussed in the section below, which include conducting automatic clash detection to eliminate inconsistency between architectural, structural, and 
Z. Liu, M. Osmani, P. Demian \& A. Baldwin (2015) A BIM-aided construction waste minimisation framework. Automation in Construction, Volume 59, November 2015, Pages 1-23.

services models; applying material outline specifications to architectural, structural, and services area model components; conducting analysis exercises from material outline specification of architectural, structural, and services model components to evaluate and minimise the material and component wastage coordinated with SSDD model; estimating total virtual waste generation for each SSDD model component; producing a Design Development virtual waste minimisation report; and updating BIM database.

\subsubsection{Low-level BaW Framework Design Development evaluation process}

The interview showed that the use of BIM for clash detection, detailing, and visualisation and simulation to assist design decision making, can help in reducing construction waste by avoiding design changes during the construction stage.

In terms of addressing design coordination errors, automatic clash detection should be conducted to inspect design coordination and check for inconsistency between architectural, structural, and services area models. Thus, a fully checked and coordinated architectural, structural, and services model component is established to apply material outline specifications. This would facilitate the use of materials through the specified five steps related to individual model components of architectural, structural, and services area models, as shown in Fig. 9. These steps comprise locating each component, creating material for the component, creating surface pattern for the material in line with outline specification, setting the pattern repeat, and assigning the material to the component. 


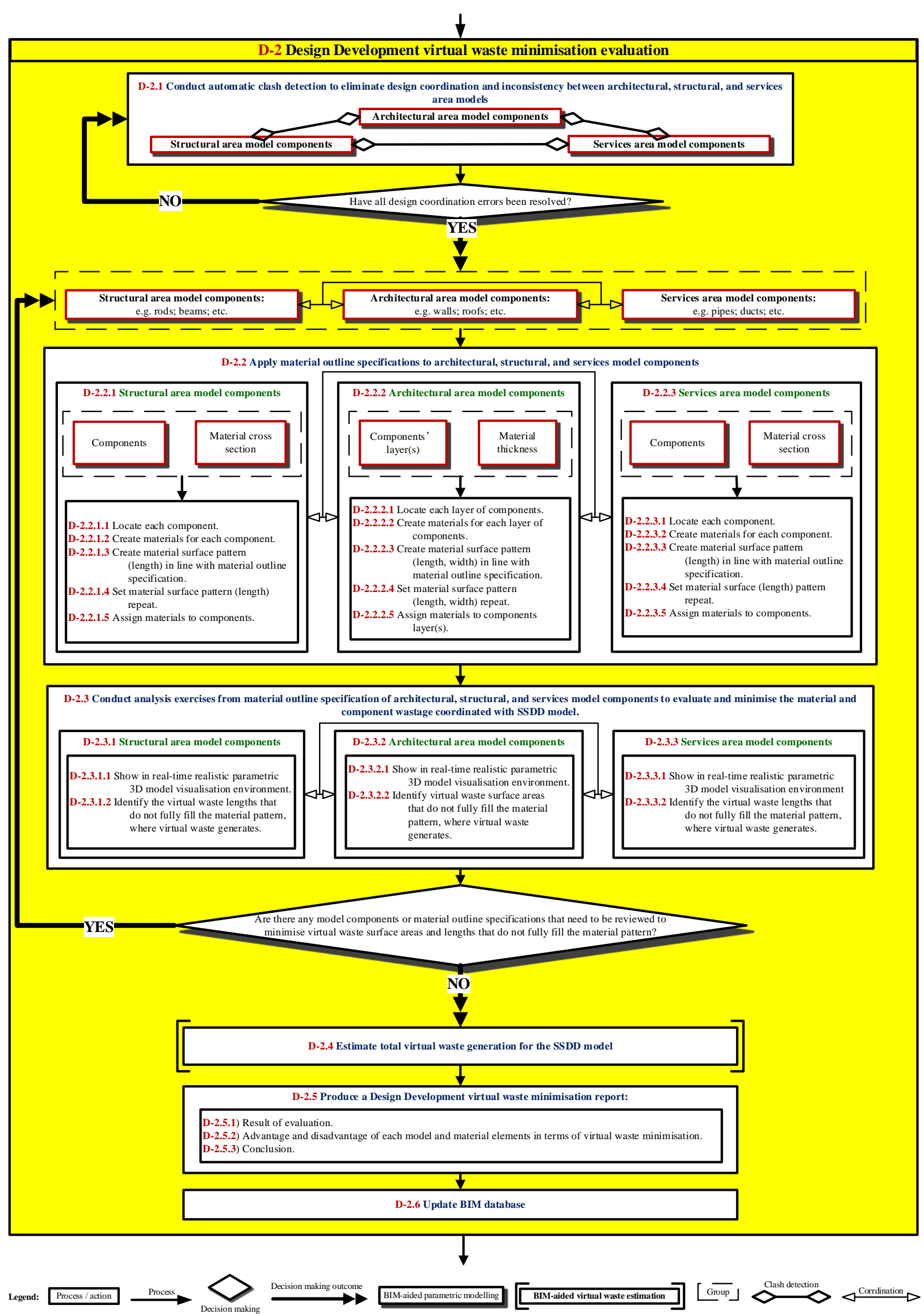



in Construction, Volume 59, November 2015, Pages 1-23.

Fig. 9. Low-level BaW Framework Design Development evaluation process component

The 'virtual' waste analysis is based on the applied outline material specification of the SSDD model and can be performed by visual inspection of material and component wastage in the 3D virtual environment through two identified steps. The two action steps are used for the architectural area model components by generating the realistic parametric $3 \mathrm{D}$ model visualisation environment in realtime. Thereafter, the 'virtual' waste surface areas that do not fully fill the material pattern where 'virtual' waste generates, can be identified.

All the SSDD model components (i.e. architectural, structural, and services area model components) with material outline specifications should be examined by estimating total 'virtual' waste generation for each SSDD model component. This would inform the quantitative estimation of total 'virtual' waste generation.

The process of estimating the total 'virtual' waste generation for the SSDD model component (D-2.4 in Fig. 9) aims to calculate waste volume in line with the set CWM target in the High-level Framework, which is described in the sections below.

i. Estimate total virtual waste generation for each SSDD model component, such as architectural, structural, and services area model components.

\section{Architectural area model components:}

1) Calculate virtual waste DAA: (Design Development) Architectural Area (surface area $\left(\mathrm{m}^{2}\right)$ of each virtual waste in each architectural area model component)

2) Use virtual waste (Design Development) DTa (unit thickness (m) of each virtual waste surface area in each architectural area model component) (data takeoff from architectural area model components (D-2.2.2 in Fig. 9))

3) Calculate virtual waste DAV: (Design Development) Architectural Volume (virtual waste volume $\left(\mathrm{m}^{3}\right)$ of each virtual waste in each architectural area model component) by using DAV = DAA $\times$ DTa

4) Calculate (Design Development) VDA (total virtual waste volume $\left(\mathrm{m}^{3}\right)$ of each architectural area model component) by using

$$
\mathrm{VDA}=\sum_{i=1}^{n} \mathrm{DAV} i
$$

5) Calculate (Design Development) Sum of all architectural virtual waste volume $\left(\mathbf{m}^{3}\right)$ (all architectural area model components) by using

$\sum_{i=1}^{n} \operatorname{VDA} i$

\section{Structural area model components:}

1) Use virtual waste DSA: (Design Development) Structural Area (cross section area $\left(\mathrm{m}^{2}\right)$ of each virtual waste length in each structural area model component) (data takeoff from structural area model components (D-2.2.1 in Fig. 9))

2) Calculate virtual waste (Design Development) DLs (unit length ( $m$ ) of each virtual waste lengths in each structural area model component)

3) Calculate virtual waste DSV: (Design Development) Structural Volume (virtual waste volume $\left(\mathrm{m}^{3}\right)$ of each virtual waste lengths in each structural area model component) by using DSV $=$ DSA $\times$ DLs

4) Calculate (Design Development) VDS (total virtual waste volume $\left(\mathrm{m}^{3}\right)$ of each structural area model component) by using 


$$
\mathrm{VDS}=\sum_{i=1}^{n} \mathrm{DSV} i
$$

5) Calculate (Design Development) Sum of all structural virtual waste volume $\left(\mathrm{m}^{3}\right)$ (all structural area model components) by using

$$
\sum_{i=1}^{n} \operatorname{VDS} i
$$

\section{Services area model components:}

1) Get virtual waste DBsA: (Design Development) Building Services Area (cross section area $\left(\mathrm{m}^{2}\right)$ of each virtual waste length in services area model component) (data takeoff from services area model components (D-2.2.3 in Fig. 9))

2) Get virtual waste (Design Development) DLv (unit length $(\mathrm{m})$ of each virtual waste lengths in each building services area model component)

3) Calculate virtual waste DBsV: (Design Development) Building Services volume (virtual waste volume $\left(\mathrm{m}^{3}\right)$ of each virtual waste lengths in each building services area model component) by using DBsV $=$ DBsA $\times$ DLV

4) Calculate (Design Development) VDBs (total virtual waste volume $\left(\mathrm{m}^{3}\right)$ of each building services area model component) by using

$$
\mathrm{VDBs}=\sum_{i=1}^{n} \mathrm{DBsV} i
$$

5) Calculate (Design Development) Sum of all building services virtual waste volume ( $m^{3}$ ) (all Building services area model components) by using

$$
\sum_{i=1}^{n} \operatorname{VDBs} i
$$

ii. Calculate (Design Development) Volume of overall virtual waste $\left(\mathrm{m}^{3}\right)=$ Sum of all architectural virtual waste volume $\left(m^{3}\right)+$ Sum of all structural virtual waste volume $\left(m^{3}\right)+$ Sum of all building services virtual waste volume $\left(m^{3}\right)$ i.e.

$$
\text { DVOVW ((Design Development) Volume of overall virtual waste) }\left(\mathrm{m}^{3}\right)=\sum_{i=1}^{n} \mathrm{VDA} i+\sum_{i=1}^{n} \mathrm{VDS} i+\sum_{i=1}^{n} \mathrm{VDBs} i
$$

iii. Takeoff area quantity of each floor in SSDD model to calculate and get the (Design Development) DAf (total floor Area $\left(\mathrm{m}^{2}\right)$ ) by automatic area quantity takeoff schedule calculation (data takeoff from SSDD model)

iv. Calculate Design Development Area Rate of Virtual Waste (DRvw) $\left(\mathrm{m}^{3}\right.$ per $\left.\mathrm{m}^{2}\right)$ : DVOVW $\left(\mathrm{m}^{3}\right) / \mathrm{DAf}\left(\mathrm{m}^{2}\right)$

Subsequently, a report on Design Development 'virtual' waste evaluation would be produced based on the results of the estimated total virtual waste generation; Thereafter, the BIM database would be updated for successful project coordination and communication. This facilitates the decision making as to whether the Design Development stage has been efficient in terms of attaining CWM target set in briefing requirements, Fig. 6; otherwise, Design Development processes should be revisited and reviewed.

\subsection{Industry-reviewed BaW Framework}

Please cite this article as: Z Liu, M. Osmani, P. Demian \& A. Baldwin (2015) A BIM-aided construction waste minimisation framework Automation in Construction, Volume 59, November 2015, Pages 1-23., http://dx.doi.org/10.1016/j.autcon.2015.07.020 
Z. Liu, M. Osmani, P. Demian \& A. Baldwin (2015) A BIM-aided construction waste minimisation framework. Automation in Construction, Volume 59, November 2015, Pages 1-23.

An industry review was carried out to test the BaW Framework in terms of clarity of structure, appropriateness of content, and clarity of flow; and formulate an implementation strategy. The industry review process involved six interviews with architects who had participated in the previous questionnaire and interview stages.

All participating architects agreed that the BaW Framework was clear, as shown in Table 7.

Table 7. Mean value of clarity and appropriateness of BaW Framework (industry review questionnaire's responses)

\begin{tabular}{|c|c|c|c|}
\hline Aspects & High-level & Low-level & $\begin{array}{c}\text { Evaluation process } \\
\text { components }\end{array}$ \\
\hline Clarity of the structure & 3.83 & 3.83 & 3.50 \\
\hline Appropriateness of content & 3.33 & 3.33 & 3.00 \\
\hline Clarity of flow & 3.67 & 3.67 & 3.17 \\
\hline
\end{tabular}

(1=Strongly disagree, 2=Disagree, 3=Agree, 4= Strongly agree)

The interviewees recommended a number of helpful suggestions, which were taken into consideration to refine and enhance the BaW Framework. These are:

- High-level BaW Framework: (1) involving a facility management consultant and quantity surveyor throughout all stages; (2) using knowledge feedback from BIM database to facilitate CWM-related briefing requirements in Appraisal and Design Brief stages, which requirements include target setting and benchmarking, CWM feasibility studies, agreement of BIM process, and waste assessment for capturing client's sustainability needs, which compares current CWM performance to that of previous projects; (3) adding lessons learnt of using BIM for CWM during each design stage from Concept to Production Information to the BIM knowledge management and coordination database to avoid replicated flaws in future projects; and

- Low-level BaW Framework and associated evaluation processes: adding feedback arrows to link BIM database to each design process.

According to industry-review respondents, therefore, the industry-reviewed High-level BaW Framework and Low-level BaW Framework are respectively presented in Fig. 10 and Fig. 11. 

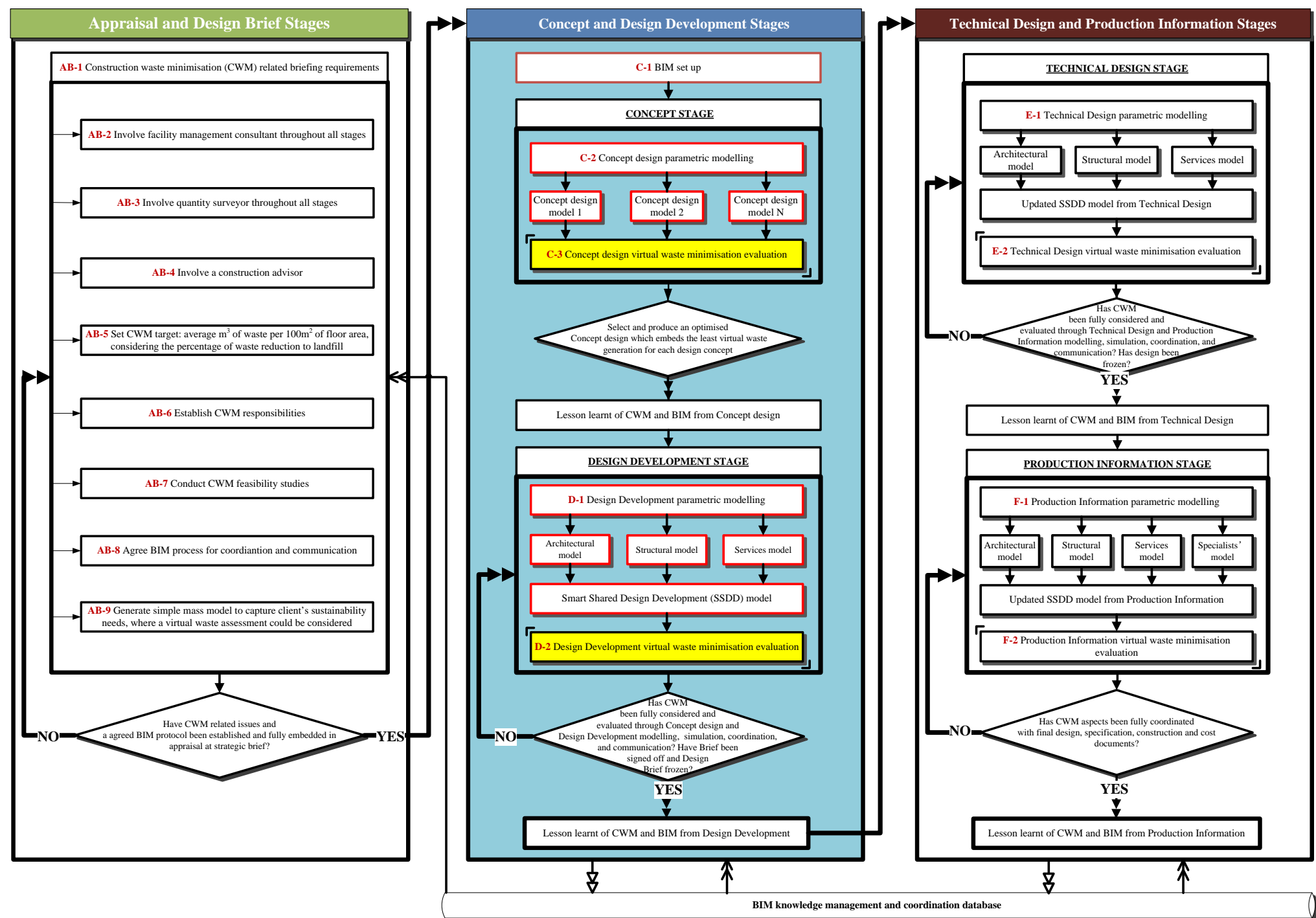

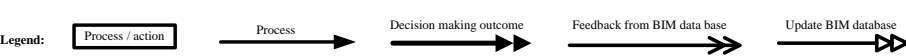

$\overbrace{\text { Berison naling }}$ 
Z. Liu, M. Osmani, P. Demian \& A. Baldwin (2015) A BIM-aided construction waste minimisation framework. Automation in Construction, Volume 59, November 2015, Pages 1-23.

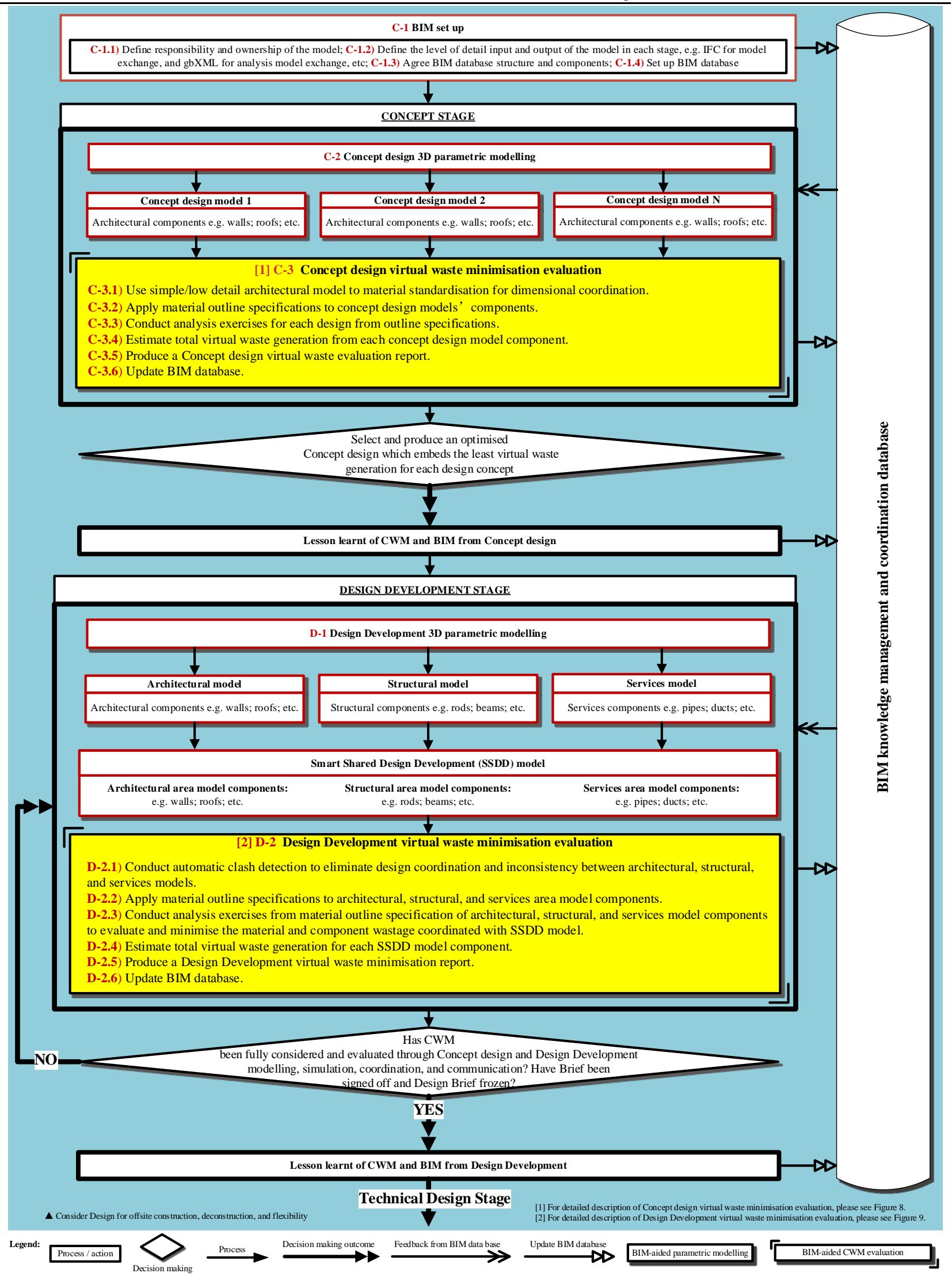

Fig. 11. Updated Low-level BaW Framework 
Nearly all the industry-review participants believed that the BaW Framework could be implemented in line with the RIBA BIM overlay, since this could be used as architects' BIM implementation plan for their design projects. Two thirds of the interviewees reported that the BaW Framework could certainly be applied to all procurement systems and building types because of its detailed outlined process for each building design stage. However, the responsibility of design changes should be clearly identified and written into the employer's requirements for Design and Build contracts. This was deemed important because contractors have control over the design process. Moreover, all interviewees collectively suggested that the BaW Framework could be implemented within environmental assessment methods, such as BREEAM, to improve construction waste-related ratings. Furthermore, nearly all interviewees indicated that the responsibility of the BaW Framework implementation should be allocated to the person who is involved in the project at both management and technical level, such as the lead designer. Two thirds of the interviewees further suggested that the development of a computer programme to facilitate 'virtual' waste estimation within the BaW Framework could improve the Framework after its implementation. The computer programme could be third-party computer software plug-ins to current BIM packages, a simple Microsoft Excel spreadsheet with well-written content, and even a 'Waste-factor (W-factor)' concept for waste evaluation calculation as a percentage of construction waste generation of building materials based on data from previous projects.

\section{Discussion and conclusions}

There is an agreement in the literature on the potential use of BIM for CWM during design stages, including BIM-aided coordination by reducing conflicts between disciplines [45]; reducing rework [23, 30, 54]; clash detection for error reduction [50]; enhancing communication and integration [30]; increasing the ability to quantify and test numerous design options of varying waste reduction performance [23]; and improving the quality of knowledge for CWM decision making [54]. The limited yet growing research in the field covers BIM-enhanced coordination for CWM [1], BIM-enhanced design waste minimisation [57, 65, 85], BIM-enhanced on-site waste management [32, 53, 64, 73], and BIM-enhanced demolition waste management [15, 31]. However, there is a complete absence of research on the development and review of tools and methodologies that use BIM to support CWM decision making during design. Additionally, no research attempts were made to relate the use of BIM to construction waste causes. As such, research reported in this paper proposed an integrated BIM-aided CWM process that addresses construction waste causes across design stages through BIM-enhanced design activities; and provides CWM performance consideration and evaluation across each design stage, to support architects to make informed CWM decisions in their projects.

The BaW Framework has been designed to be consistent with BS1192: 2007 [10], PAS1192-2: 2013 [11], and Bew-Richards's Level 2 BIM [5] with interoperable data for integrated collaboration within BIM knowledge management and coordination database environment. Hence, the BaW Framework has the capability to be implemented across Level 2 and Level 3 BIM, and could be further enhanced by developing the virtual waste evaluation component of the Framework into a computer programme, such as 'Waste-factor (W-factor)', as shown in Fig. 12. Further, based on the BaW Framework, the concept of Waste Information Model (WIM) has been added to the current BIM family, as shown in Fig. 12. Moreover, strategic CWM improvements were embedded within the briefing requirements during the Appraisal and Design Brief stages for CWM decision making in the High-level BaW Framework, as shown in Fig. 10. Hence, CWM implementation during the Briefing stage of the industry-reviewed High-level BaW Framework is also suitable for non-BIM practicing architects. Furthermore, the BaW Framework was structured in line with the RIBA Plan of Work stages, where the process of using BIM is outlined to aid waste reduction. As such, the implementation of the BaW Framework can enhance both the 'RIBA Green Overlay' and 'RIBA BIM Overlay' in the building design industry. 

in Construction, Volume 59, November 2015, Pages 1-23.

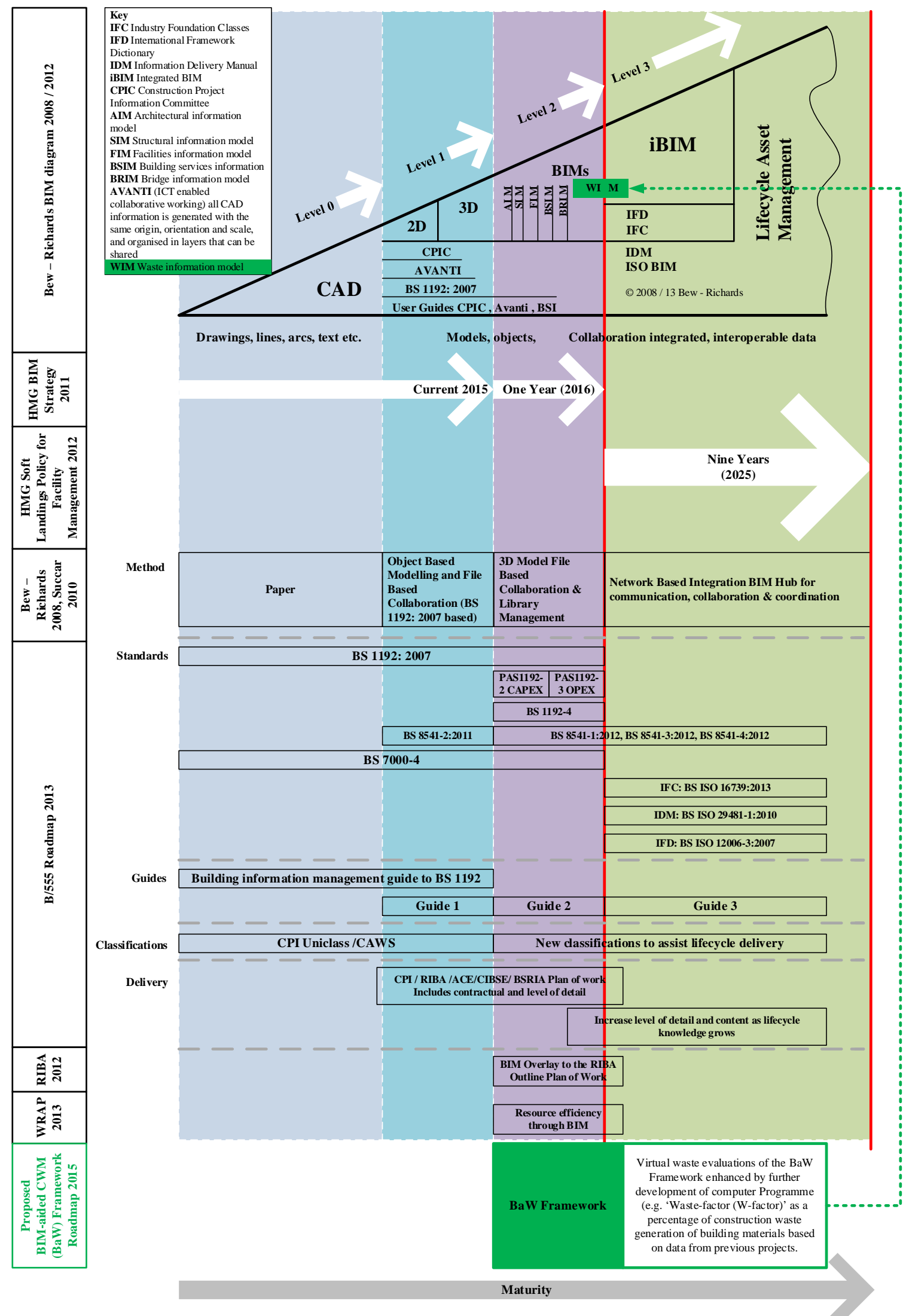

Fig. 12. Diagram of the BaW Framework in current UK's BIM maturity roadmap (devised by the authors based on the literature and the research findings) 
The research has extended the exciting knowledge towards a clear understanding of the correlation between construction waste causes during each design stage and BIM potential for improving CWM, leading to the development of the BaW Framework. The BIM potential for improving CWM included BIM-enhanced design-related activities (e.g. detailing, clash detection, visualisation and simulation, and coordination and communication) for reducing construction waste generation; BIM for addressing construction waste causes; and BIM potential for CWM in line with current architects' practices of BIM-assisted energy efficiency throughout building design stages. The industry review process revealed that BaW Framework provides an integrated CWM decision making process during design, which could be implemented within the RIBA BIM Overlay and environmental assessment methods, and is suitable for any type of building or procurement system. Finally, the BaW Framework could be adopted and customised by other building design disciplines, such as structural and building services design.

\section{Acknowledgements}

The research involved questionnaire survey and interview for data collection with participating companies which play a leading role in the UK's building design industry. A number of senior architects of those companies are acknowledged for generously giving their time and providing the most valuable information that was of vast benefit to the data collection. The research and this paper would not be possible without the research funding from the School of Civil and Building Engineering, Loughborough University, England.

\section{References}

[1] Ahankoob, A., Khoshnava, S. M., Rostami, R. and Preece, C. (2012), "BIM perspectives on construction waste reduction", in Management in Construction Research Association (MiCRA) Postgraduate Conference, pp. 195-199.

[2] Al-Hajj, A. and Hamani, K. (2011), "Material Waste in the UAE Construction Industry: Main Causes and Minimisation Practices", Architectural Engineering and Design Management, Vol 7, No. 4, pp. 221-235.

[3] Alwi, S., Hampson, K. and Mohamed, S. (2002), "Waste in the Indonesian Construction Project", in Proceedings of the 1st International Conferences of CIB W107 - Creating a Sustainable Construction Industry in Developing Countries, pp. 305-315, November 2002, South Africa.

[4] Baldwin, A.N., Poon, C., Shen, L., Austin, S. and Wong, I. (2009), "Designing out waste in high-rise residential buildings: Analysis of precasting methods and traditional construction", Renewable Energy, Vol. 34, No. 9, pp. 2067-2073.

[5] Bew, M., and Underwood, J. (2010), "Delivering BIM to the UK Market", In J. Underwood \& I. Umit (Eds.), Handbook of Research on Building Information Modeling and Construction Informatics: Concepts and Technologies, IGI Global, pp. 30-64.

[6] Blengini, G.A. and Garbarino, E. (2010), "Resources and waste management in Turin (Italy): the role of recycled aggregates in the sustainable supply mix", Journal of Cleaner Production, vol. 18, no. 10-11, pp. 1021-1030.

[7] Bossink, B.A.G. and Brouwers, H.J.H. (1996), "Construction waste: quantification and source evaluation", Journal of Construction Engineering and Management, Vol. 122, No. 1, pp. 55-60.

[8] Braun, J., Cho, Y. K. and Li, H. (2010), "Editorial: Expanding BIM to Meet the Grand Challenges in Buildings-What is 
Z. Liu, M. Osmani, P. Demian \& A. Baldwin (2015) A BIM-aided construction waste minimisation framework. Automation in Construction, Volume 59, November 2015, Pages 1-23.

Needed?", HVAC\&R Research, Vol. 16, No. 5, pp. 543-544.

[9] BRE. (2001), "SMARTWaste”, Available at: http://www.smartwaste.co.uk/ (accessed 17 January 2011).

[10] BSi. (2008), BS1192:2007 Collaborative production of architectural, engineering and construction information - Code of practice, BSi, London, UK.

[11] BSi. (2013), PAS 1192-2:2013 Incorporating Corrigendum No. 1 - Specifi cation for information management for the capital/delivery phase of construction projects using building information modelling, BSi, London, UK.

[12] Building Magazine. (2010), "Top 100 Architects", Available at:

http://www.building.co.uk/Journals/43/Files/2010/10/7/054_BUILDING40.pdf (accessed 16 June 2011).

[13] Chen, Z., Li, H., and Wong, C.T.C. (2002), "An application of bar-code system for reducing construction wastes". Automation in Construction, vol.11, no. 5, pp. 521-533.

[14] Chen, Z., Li, H., Kong, S.C.W., Hong, J. and Xu, Q. (2006), "E-commerce system simulation for construction and demolition waste exchange", Automation in Construction, vol. 15, no. 6, pp. 706-718.

[15] Cheng, C. P. and Ma, Y.H. (2013), "A BIM-based system for demolition and renovation waste estimation and planning", Waste Management, Vol.33, No. 6, pp. 1539-1551.

[16] Crittenden, B.D. and Kolaczkowski, S.T. (1995), Waste minimization: a practical guide, Institution of Chemical Engineers, Rugby.

[17] Dainty, A.R.J. and Brooke, R.J. (2004), "Towards improved construction waste minimisation: a need for improved supply chain integration", Structural Survey, vol. 22, no. 1, pp. 20-29.

[18] Davies, R. and Harty, C. (2013), "Implementing 'Site BIM': A case study of ICT innovation on a large hospital project", Automation in Construction, vol. 30, pp. 15-24.

[19] Defra. (2004), "e-Digest Environment Statistics, Waste and recycling", Available at: http://archive.defra.gov.uk/evidence/statistics/environment/waste/kf/wrkf02.htm (accessed 25 September 2013).

[20] Defra. (2007), "Consultation on site waste management plans for the construction industry", Available at: http://www.secbe.co.uk/documents/consultation_on_site_waste_management_plans_for_the_construction_industry.pdf (accessed 20 February 2013).

[21] Defra. (2008), Construction Resources and Waste Roadmap 2008, Building Research Establishment (BRE), Watford, UK.

[22] Defra. (2013), "Waste Prevention Programme for England Call for evidence", Available at: https://www.gov.uk/government/uploads/system/uploads/attachment_data/file/221130/wpp-consult-doc-20130311.pdf (accessed 22 September 2013). 
[23] Eastman, C., Teicholz, P., Sacks, R. \& Liston, K. (2008), BIM Handbook: A Guide to Building Information Modeling for Owners, Managers, Designers, Engineers and Contractors, John Wiley \& Sons, Inc., Canada.

[24] Ekanayake, L.L. and Ofori, G. (2000), "Construction material waste source evaluation", in Proceedings of 2nd Southern African Conference on Sustainable Development in the Built Environment: Strategies for a sustainable built environment, Pretoria, South Africa.

[25] Ekanayake, L. L. and Ofori, G. (2004), "Building waste assessment score: design-based tool". Building and Environment, Vol. 39, pp. 851-861.

[26] Environment Agency. (2003), "Sustainable Construction: Position Statement", Available at: http://www.environment-agency.gov.uk/cy/ymchwil/lyfrgell/safbwynt/41239.aspx (accessed 20 February 2013).

[27] Faniran, O.O. and Caban, G. (1998), "Minimizing waste on construction project sites", Engineering Construction and Architectural Management, Vol. 5, No. 2, pp. 182-188.

[28] Gavilan, R.M. and Bernold, L.E. (1994), "Source Evaluation of Solid Waste in Building Construction", Journal of construction engineering and management, Vol. 120, No. 3, pp. 536-552.

[29] Greenwood, D., Horne, M., Thompson, E. M., Allwood, C. M., Wernemyr, C. and Westerdahl, B. (2008), "Strategic Perspectives on the Use of Virtual Reality within the Building Industries of Four Countries". Architectural Engineering and Design Management, vol. 4, no. 2, pp. 85-98.

[30] Hardin, B. (2009), BIM and construction management: proven tools, methods, and workflows, 1st edn, Wiley Publish, Inc, Canada.

[31] Hamidi, B., Bulbul, T., Pearce, A. and Thabet, W. (2014), "Potential Application of BIM in Cost-benefit Analysis of Demolition Waste Management". In Construction Research Congress, pp. 279-288.

[32] Hewage, K. and Porwal, A. (2012), "Sustainable Construction: An Information Modelling Approach for Waste Reduction", Available at: http://www.iiirr.ucalgary.ca/files/iiirr/148.pdf (accessed 04 May 2012).

[33] HM Government (2008), "Strategy for sustainable construction", Available at: http://www.bis.gov.uk/files/file46535.pdf (accessed 22 September 2013).

[34] HM Government. (2011), "Government Construction Strategy 2011", Available at: https://www.gov.uk/government/uploads/system/uploads/attachment_data/file/61152/Government-Construction-Strategy_ 0.pdf (accessed 22 September 2013).

[35] HM Government. (2012), "Building Information Modelling”. Industrial strategy: government and industry in partnership, BSi, London.

[36] HM Government. (2013), "Construction 2025: Industrial Strategy: government and industry in partnership", Available 
Z. Liu, M. Osmani, P. Demian \& A. Baldwin (2015) A BIM-aided construction waste minimisation framework. Automation in Construction, Volume 59, November 2015, Pages 1-23.

at:

https://www.gov.uk/government/uploads/system/uploads/attachment_data/file/210099/bis-13-955-construction-2025-indu strial-strategy.pdf (accessed 22 September 2013).

[37] HM Revenue \& Customs. (2013), "A general guide to Landfill Tax", Available at: http://customs.hmrc.gov.uk/channelsPortalWebApp/channelsPortalWebApp.portal?_nfpb=true\&_pageLabel=pageExcise _ShowContent\&propertyType=document\&id=HMCE_CL_000509 (accessed 22 September 2013).

[38] Howard, R. and Björk, B. (2008), "Building information modelling - Experts' views on standardisation and industry deployment", Advanced Engineering Informatics, vol. 22, no. 2, pp. 271-280.

[39] Innes, S. (2004), "Developing tools for designing out waste pre-site and on-site", in Proceedings of Minimising Construction Waste Conference: Developing Resource Efficiency and Waste Minimisation in Design and Construction, New Civil Engineer, London.

[40] Irizarry, J., Karan, E. P. and Jalaei, F. (2013), "Integrating BIM and GIS to improve the visual monitoring of construction supply chain management". Automation in Construction, vol. 31, pp. 241-254.

[41] Iwaro, J., Mwasha, A., Williams, R. G. and Zico, R. (2014), "An Integrated Criteria Weighting Framework for the sustainable performance assessment and design of building envelope", Renewable and Sustainable Energy Reviews, Vol.28, pp. 417-434.

[42] Keller, T. and Tergan, S.O. (2005), "Visualizing knowledge and information: an introduction". Knowledge and Information Visualization, vol. 3426, pp. 1-23.

[43] Keys, A., Baldwin, A.N. and Austin, S.A. (2000), "Designing to encourage waste minimisation in the construction industry". CIBSE (Chartered Institute of Building Services Engineers).

[44] Kim, H. and Grobler, F. (2009), "Design Coordination in Building Information Modeling (BIM) Using Ontological Consistency Checking", Computing in civil engineering - ASCE, pp. 410-420.

[45] Krygiel, E. \& Nies, B. (2008), Green BIM: Successful Sustainable Design with Building Information Modeling, John Wiley \& Sons, Inc., Canada.

[46] Lagüela, S., Díaz-Vilariño, L., Martínez, J. and Armesto, J. (2013), "Automatic thermographic and RGB texture of as-built BIM for energy rehabilitation purposes", Automation in Construction, vol. 31, pp. 230-240.

[47] Li, H., Chen, Z., Yong, L. and Kong, S.C.W. (2005), "Application of integrated GPS and GIS technology for reducing construction waste and improving construction efficiency", Automation in Construction, vol. 14, no. 3, pp. 323-331.

[48] Liu, Z., Osmani, M., Demian, P., and Baldwin, A. N. (2011), "The potential use of BIM to aid construction waste minimalisation". In Proceedings of the CIB W78-W102 2011: International Conference, 26th-28th October 2011, Sophia Antipolis, France, paper 53. 
Z. Liu, M. Osmani, P. Demian \& A. Baldwin (2015) A BIM-aided construction waste minimisation framework. Automation in Construction, Volume 59, November 2015, Pages 1-23.

[49] Love, P.E.D., Li, H. and Mandal, P. (1999), "Rework: a symptom of a dysfunctional supplychain", European Journal of Purchasing and Supply Management, Vol. 5, pp. 1-11.

[50] Love, P. E., Lopez, R. \& Edwards, D. J. (2013), "Reviewing the past to learn in the future: making sense of design errors and failures in construction", Structure and Infrastructure Engineering: Maintenance, Management, Life-Cycle Design and Performance, Vol. 9, No. 7, pp. 675-688.

[51] McGraw-Hill (2008), Building Information Modeling (BIM): Transforming Design and Construction to Achieve Greater Industry Productivity, McGraw-Hill Construction, New York.

[52] Muhwezi, L., Chamuriho, L. M., and Lema, N. M. (2012), "An investigation into Materials Wastes on Building Construction Projects in Kampala-Uganda", Scholarly Journal of Engineering Research, Vol. 1, No. 1, pp. 11-18.

[53] Ningappa, G. (2011), "Use of Lean and Building Information Modeling (BIM) in the Construction Process; Does BIM make it Leaner?", Master degree thesis, Georgia Institute of Technology, USA.

[54] Nisbet, N. \& Dinesen, B. (2010), Building information modelling: construction the business case, British Standards Institution, London.

[55] NBS. (2013), National BIM Report 2013, Newcastle. UK.

[56] NSCC. (2007), "Reduce, Reuse, Recycle Managing your waste", Available at: http://www.nscc.org.uk/docs/general/002fGuidanceonwaste.pdf (accessed 22 September 2013).

[57] O'Reilly, A. (2012), "Using BIM as a tool for cutting construction waste at source". CIOB Construction Research and Innovation, Vol. 3, No. 1, pp. 28-31.

[58] Osmani, M. (2012), "A Kaleidoscope Evaluation of Construction Waste Management in the UK", in CRETE 2012: 3rd International Conference on Industrial and Hazardous Waste Management.

[59] Osmani, M. (2013), "Design waste mapping: a project life cycle approach", Proceedings of the ICE - Waste and Resource Management, Vol. 166, No. 3, pp. 114-127.

[60] Osmani, M., Glass, J. and Price, A.D.F. (2008), "Architects' perspectives on construction waste reduction by design", Waste Management, Vol. 28, No. 7, pp. 1147-1158.

[61] Panos, K. and Danai, G. I. (2012), "Survey Regarding Control and Reduction of Construction Waste", in PLEA2012 28th Conference, Opportunities, Limits \& Needs Towards an environmentally responsible architecture, Lima, Perú.

[62] Polat, G. and Ballard, G. (2004), "Waste in Turkish construction: need for lean construction techniques", in 12th Annual Conference on lean construction, Denmark, IGLC, Copenhagen, Denmark.

[63] Poon, C.S., Yu, A.T.W., and Ng, L.H. (2003), "Comparison of low waste building technologies adopted in public and private housing projects in Hong Kong", Engineering, Construction and Architectural Management, Vol.10, No. 2, pp. 
88-98.

[64] Porwal, A. (2013), "Construction waste management at source: a building information modeling based system dynamics approach", Doctoral Thesis, the University of British Columbia, Canada.

[65] Porwal, A. and Hewage, K. N. (2012), "Building Information Modeling-Based Analysis to Minimize Waste Rate of Structural Reinforcement”, Journal of construction engineering and management, Vol.138, pp. 943-954.

[66] Prism environment. (2012), "Construction sector overview in the UK", Available at: http://www.prismenvironment.eu/reports_prism/UK_PRISM_Environment_Report_EN.pdf (accessed 24 September 2013).

[67] Razavi, S. N. and Haas, C. T. (2010), "Multisensor data fusion for on-site materials tracking in construction", Automation in Construction, vol. 19, no. 8, pp. 1037-1046.

[68] Redmond, A., Hore, A., Alshawi, M. and West, R. (2012), "Exploring how information exchanges can be enhanced through Cloud BIM". Automation in Construction, vol. 24, pp. 175-183.

[69] RIBA. (2011), "Green Overlay to the RIBA Outline Plan of Work", Available at: http://www.ribabookshops.com/uploads/9a0204f4-8775-d644-c9d1-b2d508c5924b.pdf (accessed 22 September 2013).

[70] RIBA. (2012), "BIM Overlay to the RIBA Outline Plan of Work", Available at: http://www.architecture.com/Files/RIBAProfessionalServices/Practice/General/BIMOverlaytotheRIBAOutlinePlanofWork2 007.pdf (accessed 22 September 2013).

[71] Riemer, J. and Kristoffersen, M. (1999), Information on waste management practices, European Environmental Agency, Copenhagen, Denmark.

[72] Rounce, G. (1998), "Quality, waste and cost considerations in architectural building design management", International Journal of Project Management, Vol. 16, No. 2, pp. 123-127.

[73] Sacks, R., Koskela, L. J., Dave, B. A. and Owen, R. (2010), "The interaction of lean and building information modeling in construction", Journal of Construction Engineering and Management, Vol. 136, No. 9, pp. 968-980.

[74] Santos, A. Formoso, C. T. and Tookey J. E. (2002), "Expanding the meaning of standardisation within construction processes", The TQM Magazine, Vol.14, No. 1, pp. 25-33.

[75] Shelden, D. (2013), “Networked Space”. Architectural design, vol. 83, no. 2, pp. 36-41, John Wiley \& Sons, United Kingdom.

[76] Shen, W., Hao, Q. and Xue, Y. (2012), "A loosely coupled system integration approach for decision support in facility management and maintenance". Automation in Construction, vol.25, pp. 41-48.

[77] Sinclair, K. M. (2005), "Construction and Demolition Waste Reduction Project-SMF 4194", Available at: 
Z. Liu, M. Osmani, P. Demian \& A. Baldwin (2015) A BIM-aided construction waste minimisation framework. Automation in Construction, Volume 59, November 2015, Pages 1-23.

http://www.branz.co.nz/cms_show_download.php?id=f41f5e4783639c1e94058911d9cf6caca3fb2cb2 (accessed 22 September 2013).

[78] Skoyles, E.R. and Skoyles, J.R. (1987), Waste Prevention on Site, Mitchell Publishing, London.

[79] UK Green Building Council. (2013), "Waste", Available at: http://www.ukgbc.org/content/waste (accessed 22 September 2013).

[80] Whyte, J. (2012), "Building Information Modelling in 2012: Research Challenges, Contributions, Opportunities", Working Paper, vol. 5, Design Innovation Research Centre, University of Reading, UK.

[81] Wong, F.W.H., Lam, P.T.I., Chan, A.P.C. and Chan, E.H.W. (2006), "A Review of Buildability Performance in Hong Kong and Strategies for Improvement", Surveying and Built Environment, Vol.17, No. 2, pp. 37-48.

[82] WRAP. (2007a), "Reducing material wastage in construction", Available at: http://www2.wrap.org.uk/downloads/Reducing_Material_Wastage_in_Construction.6bf7495b.4711.pdf (accessed 22 September 2013).

[83] WRAP. (2007b), "Achieving effective waste minimisation through design", Available at: http://www2.wrap.org.uk/downloads/Design_FINAL.fe938b65.4821.pdf (accessed 22 September 2013).

[84] WRAP. (2011), "Welcome to WRAP's Waste forecasting tools", Available at: http://nwtool.wrap.org.uk/ (accessed 17 January 2011).

[85] WRAP. (2013), "BIM (Building Information Modelling) utilisation to achieve resource efficiency in construction: Leeds Arena", Available at: http://www.wrap.org.uk/sites/files/wrap/Leeds_Arena_FINAL.pdf (accessed 04 January 2013).

[86] WRAP. (2013b), "BIM and Resource Efficiency", Available at: http://www.wrap.org.uk/content/bim-and-resource-efficiency (accessed 21 May 2013).

[87] Xie, H., Shi, W. and Issa, R.R.A. (2010), "Implementation of BIM/RFID in computer-aided design-manufacturing-installation process". Computer Science and Information Technology (ICCSIT), 2010 3rd IEEE International Conference, vol. 2, pp. 107-111, July 2010, Chengdu

[88] Yan, W., Culp, C. and Graf, R. (2011), "Integrating BIM and gaming for real-time interactive architectural visualization". Automation in Construction, vol.20, no. 4, pp. 446-458. 